\title{
Acceptance of Long Work Hours in Public Accounting: Contemporary Conflicts across Hierarchical Levels
}

\author{
Lisa Baudot \\ Associate Professor \\ Kenneth G. Dixon School of Accounting \\ University of Central Florida \\ lisa.baudot@ucf.edu \\ Khim Kelly \\ Professor \\ Kenneth G. Dixon School of Accounting \\ University of Central Florida \\ khim.kelly@ucf.edu \\ Aaron McCullough \\ $\mathrm{PhD}$ Student \\ Kenneth G. Dixon School of Accounting \\ University of Central Florida \\ aaron.mccullough@ucf.edu
}

July 18,2020

We thank Chris Agoglia, Bertrand Malsch, Kim Westermann, Arnie Wright and anonymous reviewers at the 2020 Annual Congress of the European Accounting Association, the 2020 Joint Conference and Doctoral/Early Scholar Consortium of the Public Interest and Gender Issues and Worklife Balance Sections, and the 2020 American Accounting Association Annual Meeting Auditing Section for helpful comments and suggestions. We are especially grateful to firm personnel who facilitated and participated in our interviews. 


\title{
Acceptance of Long Work Hours in Public Accounting: Contemporary Conflicts across Hierarchical Levels
}

\begin{abstract}
Prior research indicates that the socialization of personnel into accepting the norms of long work hours is fundamental to how accounting firms function. However, the acceptance of such norms is potentially challenged by contemporary logics about work hours held by recent entrants to the profession. Using a sample of 26 semi-structured interviews of personnel across three hierarchical levels at a national accounting firm, we examine conflicts in multiple logics about work hours and the firm's responses to those conflicts. We find polarization in logics about work hours, which the firm addresses through various means, including flexible work practices. The firm frames such practices as achieving an acceptable degree of compatibility between the competing logics, yet personnel do not fully incorporate this view. Our study enriches our understanding of contemporary conflicts in the perspectives concerning work hours held by different hierarchical levels and the firm's responses to these seemingly incompatible logics.
\end{abstract}

Key Words: public accounting firms, long work hours, institutional complexity, socialization 


\section{INTRODUCTION}

Accounting firm personnel at all levels undergo a process of socialization wherein formal and informal organizational mechanisms guide the workforce on how to conduct themselves appropriately (Anderson-Gough, Grey, and Robson 2000; Carter and Spence 2014; Covaleski, Dirsmith, Heian, and Samuel 1998; Kornberger, Justesen, and Mouritsen 2011). Most of this literature indicates that organizational mechanisms produce the behaviors desired by the accounting firm and reduce tensions, even if initial struggle and resistance is evident in the process. One critical aspect of socialization relates to mechanisms which encourage accounting professionals to accept and embrace long work hours (Anderson-Gough, Grey, and Robson 2001; Coffey 1994; Lupu and Empson 2015).

Increasing commercial pressures faced by accounting firms drive the adoption of a "commercial logic" that emphasizes profitability and the heavy use of economic indicators, including those around hours (Covaleski et al. 1998; Zeff 2003a, 2003b). Mid-size accounting firms are not exempt from this trend (Durocher, Gendron, and Picard 2016b; Lander, Koene, and Linssen 2013). Yet, research indicates that younger generations desire more balance and flexibility around work hours, and prefer more focus on outcomes as opposed to hours (Buchheit, Dalton, Harp, and Hollingsworth 2016; Deloitte 2008; EY 2015; KPMG 2017; PwC 2013). This suggests an inherent tension between the behaviors desired by accounting firms and embraced by socialized senior-level personnel from older generations, versus the behaviors exhibited by junior-level personnel recruited from younger generations. ${ }^{1}$ Indeed, the Big Four accounting

\footnotetext{
${ }^{1}$ We recognize that generational differences are normally focused on age rather than hierarchical levels (Fogarty, Reinstein, and Heath 2017). However, given that accounting firms typically recruit junior-level staff from fresh graduates and these junior-level staff progress fairly systematically over time through each successive hierarchical level (or they leave the firm), successive levels are inherently associated with progressively older age groups and hence older generations. Therefore, each hierarchical level within the firm is at a similar stage in their career
} 
firms suggest that firms confront distinct generation-based attitudes and behaviors (Deloitte 2008; EY 2015; KPMG 2017; PwC 2013). Professional accounting bodies also indicate that generational tensions and conflicts extend to accounting firms of all sizes (AICPA 2019). ${ }^{2}$

Research indicates that workforce socialization processes may be more complex than previously shown (Durocher, Bujaki, and Brouard 2016a). That research suggests that accounting firms must adapt to the attitudes and behaviors of their workforce, yet questions whether those adaptations genuinely reduce contradiction and enable the firm to overcome workforce tensions and conflicts. Along these lines, this study explores tensions and conflicts experienced across different hierarchical levels that are inherently associated with different generations, including whether and how traditional workforce expectations are being challenged by recent entrants into the profession who are from a younger generation. We also examine how the accounting firm responds to this emerging challenge in socializing recent entrants, demonstrating that socialization processes may not work in the same way as in the past.

To address our research questions, we conduct 26 interviews of personnel at all levels within a national, mid-size U.S. accounting firm that belongs to a global network of independent advisory and accounting firms (hereafter "the firm"). The firm has been steadily growing and confronts workforce issues associated with not only the growing size of the workforce but its composition across different hierarchical levels. We use semi-structured interviews at the junior, mid-, and exec-levels to analyze comparative workforce attitudes and behaviors, and the perception of tensions and conflicts related to these attitudes and behaviors.

We situate our study in the literature on institutional complexity which describes how

progression shaped by their common exposure to organizational mechanisms. We further explain the nature and composition of the workforce at the junior-, mid- and exec-level in our research method section.

${ }^{2}$ Other commentators question whether actual generational differences in workforce attitudes and behaviors exist (Fogarty et al. 2017), even if they are perceived to be important (King, Finkelstein, Thomas, and Corrington 2019). 
organizations may confront tensions due to multiple institutional logics (Greenwood, Raynard, Kodeih, Micelotta, and Lounsbury 2011; Vermeulen, Zietsma, Greenwood, and Langley 2016). Institutional logics are overarching norms, values, and beliefs by which we give meaning to our daily lives (Thornton, Ocasio, and Lounsbury 2012). In many situations, multiple logics impose incompatible demands on organizations and their members (Pache and Santos 2010). Institutional complexity focuses on how organizations manage those incompatible demands through their structural configurations, strategies, and practices (Jarzabkowski, Smets, Bednareck, Burke and Spee 2013; Smets, Morris, and Greenwood 2012; Smets, Jarzabkowski, Burke, and Spee 2015; McPherson and Sauder 2013; Pache and Santos 2013), particularly when such demands conflict with logics central to the functioning of the organization (Jay 2013). We argue that accounting professionals' attitudes and behaviors around hours are part of a system of logics that characterize accounting firm personnel at different levels. These attitudes and behaviors may be consistent with or at odds with the accounting firm's expectations. We refer to a relational model of institutional complexity (Smets and Jarzabkowski 2013) to shed light on firm and workforce attitudes and behaviors at different levels within an organization, and how tensions and conflicts between them emerge and evolve in practice.

Our analysis shows that the attitudes and behaviors of more senior levels (i.e., mid- and exec-level) differ from those of the junior-level, particularly around work hours. More senior levels perceive the junior-level as not "working hard" enough in accumulating billable hours and not "working smart" enough in leveraging efficiency to generate more billable hours. For the more senior levels, working more efficiently means being able to generate more billable hours, while the junior-level suggests that working more efficiently is a substitute for the accumulation of billable hours. These differences in attitudes and behaviors around work hours create 
institutional complexity as the perspectives of the junior-level conflicts with that of more senior levels whose perspectives align more with the firm-level commercial logic.

We also note a polarization in attitudes and behaviors on work hours by the different levels as each level is entrenched in its own logic. More senior levels evidence entrenchment by rationalizing long work hours through the benefits that arise to juniors in terms of more learning and growth opportunities. They also legitimate long work hours through mechanisms that allow comparisons to peers who work the longest hours. Likewise, the junior-level largely remains entrenched in their own logic, evaluating negatively the attempt of more senior levels to reframe work hours as opportunities and delegitimizing the attitudes and behaviors of peers who work the longest hours. Repeated polarization and entrenchment trigger a "work-level crisis" where the completion of normal work functions becomes difficult. Resolving a "work-level crisis" demands that the different levels acknowledge the severity of the institutional complexity and reconstruct what is experienced as contradictory in a way that is compatible. The more senior levels try adapting the firm-level commercial logic in a way that accommodates the perspectives of juniors on work hours, via experimenting with flexible work arrangements. This flexibility aims to satisfy the firm's expectation of long work hours with the ability to choose when and where those hours are worked, while repackaging work hours as integrated with non-work hours. The emergence of an expanded practice repertoire around flexible work arrangements aims to bridge the firm-level commercial logic and the perspectives of junior-level personnel, closing the perceived gap between working harder and working smarter.

Our research contributes to the literature on managing accounting firms, professionals, and their work practices in several ways. We contribute to understanding challenges in the socialization of accounting professionals (Anderson-Gough et al. 2000; Durocher et al. 2016a; 
Kornberger et al. 2011; Pentland 1993) to the extent that accounting firms experience increasing difficulties in socializing entrants to the profession. Our work identifies how such socialization difficulties may be due to recent attitudes and behaviors around work hours that conflict with traditional attitudes and behaviors embedded in the firm-level commercial logic. We highlight how the firm's socialization challenges may be linked to managing a workforce that comprises multiple generations (Durocher et al. 2016b; Fogarty et al. 2017). While socialization processes seem to be primarily upset by changes in attitudes held by the junior-level, there is indication that the mid-level's exposure to the perspectives of the junior-level creates subsequent reflection on their own logic towards work hours. This suggests that we have more to learn not only about whether the firms must consider incompatibilities between traditional socialization mechanisms and recent entrants to the profession, but also about the presumed resilience of socialization processes within accounting firms.

Finally, theories of institutional complexity largely examine organizational responses to macro-level conflicts in organizational logics. In contrast, a relational model of institutional complexity focuses on the responses of individuals to intra-organizational conflicts in logics. We show how a relational model of institutional complexity (Smets and Jarzabkowski 2013) helps us appreciate responses to competing firm- and workforce-level logics around work hours in the accounting profession (Anderson-Gough et al. 2001; Coffey 1994; Lupu and Empson 2015). Our work suggests that accounting firms and personnel might come to see logics that originally seem polarized as compatible through the design of mechanisms that reduce tensions on both sides. Thus, our research speaks to accounting firm managerial strategies and mechanisms that balance the firm's economic goals with employees' interests (Buchheit et al. 2016).

The rest of the paper is organized as follows. First, we review the literature on accounting 
firm socialization of work attitudes and behaviors. Next, we discuss institutional complexity as an analytical lens through which we can understand contradictions between the perspectives of the accounting firm and professionals across different hierarchical levels. We then describe the research method, after which we present the findings of our study. We conclude with a discussion and avenues for future research.

\section{LITERATURE REVIEW}

Research describes increasing commercial pressures exerted on public accounting firms of all sizes over the past 30 years, including concentration of firms, reduction of clientele, and standardization of audit procedures (Malsch and Gendron 2013). Commercial pressures exacerbate the need for long hours and also drive changes in accounting firm structures towards an increased emphasis on the economics of auditing, including "the classics - realization rates, client billings, time budget averages, revenue and profit per partner" as well as utilization and billing rates of specific individuals (Covaleski et al. 1998, 316). ${ }^{3}$

Prior research examines how accounting firms institutionalize long work hours and socialize accountants into accepting and embracing those practices (Anderson-Gough et al. 2001; Coffey 1994; Grey 1998; Lupu and Empson 2015; Pentland 1993). For instance, performance measurement is a key mechanism of socializing the behavior of partners (Carter and Spence 2014; Covaleski et al. 1998) and managers (Kornberger et al. 2011). Accountants at these levels behave in accordance with mechanisms that measure their performance against the firm's expectations in terms of realization, utilization and time budgets which, in turn, drive promotion and retention decisions (Covaleski et al. 1998). Likewise, Anderson-Gough et al. (2001) and Coffey (1994) focus on the tracking and monitoring of time budgets, time-reckoning and time

\footnotetext{
${ }^{3}$ Realization refers to the relationship between charged time and budgeted time, while utilization refers to charged time as a percentage of available hours.
} 
management as important socializing facets for junior-level accountants.

Socializing mechanisms can also include mentoring and observation, as well as verbal or written validation of behavior (Covaleski et al. 1998; Dirsmith, Heian, and Covaleski 1997). Pentland (1993) notes that juniors are acutely aware of the norms set by their superiors and emulate the behavior of their superiors. Furthermore, where superiors have internalized and embody the firm's values, their validation in the performance appraisal process promotes desired organizational goals and cultivates appropriate behaviors in juniors (Anderson-Gough et al. 2001; Covaleski et al. 1998). Another socializing mechanism arises from the "quasi-compulsory" events held outside formal work hours that juniors are expected to attend, blurring the boundaries of private time and work time (Coffey, 1994).

Overall, prior research finds that the socialization process works in that although juniors exhibit initial resistance, they do ultimately accept the norms of long work hours and eventually perpetuate those norms themselves as they progress through the ranks. For example, although the juniors "did not like it, ... they seemed to have an understanding that to get on with [the firm] and to pass the examinations required a sacrifice of personal time" (Coffey 1994, 952). Juniors recognize the "need to be visible, appearing keen, busy and conscientious" (Coffey 1994, 953) and make sure others are aware of the hours they put in. Pentland $(1993,616)$ finds that "although everyone objects to the hours, there is a great deal of respect among auditors for the people who put in the most" and that "putting in long hours of overtime is an important way to earn your badge of honor as an audit machine." Anderson-Gough et al. $(2001,112)$ show that for juniors "overtime was a normal expectation ... Failure to perform and even a lack of enthusiasm for overtime were believed ... to damage severely an individual's career prospects". Lupu and Empson (2015) interview partners and senior managers and observe that the desire to attain and 
retain the economic capital and the symbolic capital (i.e., reputation or prestige) associated with long hours explains why autonomous professionals "comply with organizational pressures to overwork". Interestingly, Lupu and Empson $(2015,1327)$ note that "as they work relentlessly long hours they have no time for the reflexivity required to question how things are done" and "as a result, unable to resist, they comply with and perpetuate the rules of the game."

However, Anderson-Gough et al. (2001) conducted interviews in 1996-1997 meaning the juniors interviewed fall into Generation X (born approximately between 1965 to 1980). ${ }^{4}$ Lupu and Empson (2015) focus on senior managers and partners who are also not in the Millennial generation (born approximately between 1980-1995). In contrast, our study represents a cross section of generations at different levels, ranging from juniors who fall into the Millennial generation to partners who are part of older generations (i.e., Generation X or Baby Boomers). Research suggests fundamental changes in the attitudes of entrants into the accounting profession over the past two decades (Durocher et al. 2016a). Recent entrants see their job as enabling them to do the things they want to do rather as the thing they want to do in life (Durocher et al 2016a). This has been linked to wanting to "clock off" once the official workday ends and to focus on outcomes rather than the amount of time put in (Deloitte 2008; KPMG 2017). Ng, Schweitzer, and Lyons (2010) also indicate that recent entrants have distinct expectations for work-life balance and flexibility, desiring to control their hours and location (KPMG 2017). Millennials are said to attribute even more importance to balance and flexibility and are more likely than prior generations to leave a job when they don't have that balance (EY 2015).

Whether generational differences in attitudes and behaviors exist remains disputed (e.g.

\footnotetext{
${ }^{4}$ Today's workforce consists of three distinct generations: the Baby Boomers (born 1946-1964), Generation X (born 1965 - 1979), and Millennials (born about 1980-1995) (KPMG 2017). Accounting firms are now mainly recruiting younger Millennials and preparing for the entrance of Generation Z (born 1996 - 2010) (KPMG 2017). These generational divisions are approximate but generally align with prior research (Durocher et al. 2016a).
} 
Costanza and Finkelstein 2015; Fogarty et al. 2017; Weiner and Rasch 2015). However, King et al. (2019) argue that it is not so much actual generational differences but the perception of differences that matters. Perceptions around changes in the attitudes and behaviors of recent entrants to the profession may present a shock to traditional socialization mechanisms within accounting firms that institutionalize long work hours. At the same time, research indicates that progression to higher ranks within the organization contributes to the adoption of organizational goals and the reduction of conflict (Suddaby, Gendron, and Lam 2009). Our work speaks to potential conflicts in workforce attitudes and behaviors across hierarchical levels and how an accounting firm manages and responds to conflicts that are perceived to be generational in nature. Next, we present the theoretical lens used to address our research questions.

\section{THEORETICAL LENS}

Logics are overarching norms, values and beliefs by which organizations (and individuals) give meaning to their daily activities (Thornton and Ocasio 1999; Thornton et al. 2012). Where there exists multiple incompatible logics, institutional complexity arises in the form of tensions and conflicts that need to be strategically managed or resolved by the organization facing the complexity (Greenwood et al. 2011). Organizational responses vary (Oliver 1991; Pache and Santos 2010), ranging from the creation of new organizational arrangements (Greenwood and Suddaby 2006) to the maintenance of existing arrangements (Hirsch and Bermiss 2009; Zietsma and Lawrence 2010).

Research on institutional complexity frequently studies organizational responses to more macro-level tensions and conflicts, where either external shocks impose or organizational-level constituents adhere to different logics, generating institutional complexity. An example is the study of the susceptibility of accounting firms to a logic of commercial gain (Gendron, Suddaby, 
and Lam 2006), that is often juxtaposed with a logic of professionalism (Suddaby, Cooper, and Greenwood 2007; Malsch and Gendron 2013). However, there is a relative neglect of studying tensions and conflicts that are micro-level which generate relational institutional complexity between internal organizational actors and the organization (Malsch and Gendron 2013; McPherson and Sauder 2013). One reason for the neglect of micro-level analysis relates to a key assumption of institutional theory that actors affiliated with a professional or organizational group will closely adhere to that group's primary logic (McPherson and Sauder 2013). As such, accounting firm personnel would be expected to adhere closely to the primary logic exhibited by their firm. However, McPherson and Sauder (2013) find that professional actors exercise choice and power in their attitudes and behaviors. This may lead to tensions that need to be managed by the firm internally, especially where those attitudes and behaviors not only differ individually (Jarzabkowski et al. 2013; Smets et al. 2012, Smets et al. 2015; McPherson and Sauder 2013; Pache and Santos 2010), but conflict with the firm's primary logic (Jay 2013).When individuallevel logics conflict with a logic that is central to the organization's functioning, the organization is compelled to deal with such intra-institutional complexity (Meyer and Höllerer 2016).

The market for professional services is an inherently commercial activity (Carter and Spence 2014). A commercial logic suggests sensitivity to economic considerations which necessitates internal firm structures, routines and work practices that emphasize those considerations (Covaleski et al. 1998; Schneider, Wickert, and Marti 2017). Under a commercial logic, accounting firms structure the conditions by which work is produced (e.g., long hours) but may need to manage tensions associated with those conditions (Suddaby et al. 2007; Carter and Spence 2014). We argue that the attitudes and beliefs held by different hierarchical levels may align or be at odds with other levels as well as with the firm-level commercial logic and the 
importance of long hours to that logic. Contradictions experienced by and across hierarchical levels may create intra-institutional complexity for the accounting firm. In turn, the firm may respond to intra-institutional complexity through the design and promotion of organizational mechanisms aimed at influencing the logics of individuals inhabiting the organization.

The connection between the firm-level commercial logic and the logics held by individual personnel suggests that a relational model of institutional complexity may help to understand contemporary accounting firm challenges. Smets and Jarzabkowski (2013), in a study of lawyers in a global law firm, propose a relational model for understanding intra-institutional complexity. Within that model, Smets and Jarzabkowski (2013) propose four cycles linked to expressions of intra-institutional complexity. ${ }^{5}$ These authors suggest the first cycle is triggered by the introduction of institutional complexity related to the expression of alternative logics. Cycle one reveals a distance or discrepancy between the alternative expression of logics and traditional ways of thinking and behaving. That distance produces "polarization" as actors recognize the tensions and conflicts between alternative logics and their own logics.

Cycle two stimulates actors' consideration of whether the logics held by others are legitimate, and entrenchment in their own logics. Actors actively cast the others as disruptive and legitimate their own logics as being more viable. In this stage, a "work-level crisis" emerges as repeated disruptions and counter-disruptions interfere with smooth completion of work tasks. Cycle three helps us to understand how a sense of "work-level crisis" may drive actors to overcome their entrenchment and trigger mutual adjustment. Actors' responses to institutional complexity can involve reconstructing what has been previously experienced as contradictory in

\footnotetext{
${ }^{5}$ While Smets and Jarzabkowski (2013) refer to these as cycles and theorize their sequence, they also speculate about other potential paths through the model and situations in which the nature of the progression may change. This includes progressions being delayed, leaping over cycles completely, or regressions to previous cycles. Thus, the model allows for adaptation beyond a linear, sequential, and complete progression through the four cycles.
} 
a way that is now compatible. This reconstructing entails adaptations that aim to reduce the tension experienced through an "expanded practice repertoire". Finally, cycle four suggests that as this expanded practice repertoire becomes institutionalized, multiple logics move from being perceived as merely compatible to being perceived as complementary.

\section{RESEARCH METHOD}

This section describes the development of our interview instrument, the selection of participants, and the collection and analysis of our interview data. We use a qualitative, semistructured interview approach which is well suited to understanding how the world of accounting works in practice (Malsch and Salterio 2016). We did not have a hypothesis with regards to what we would find but let the data "speak for itself" in the generation of recurring patterns and themes (Power and Gendron 2015). However, once those recurring patterns and themes emerged, we understood them to be telling a story about institutional complexity and looked to the literature on this topic to help us understand and explain how firms deal with this in practice.

\section{Interview Instrument}

We developed our instrument broadly around questions of work engagement, incentives and motivation, referring to prior literature on these topics as well as insights from two former auditors in academic positions and our executive-level audit firm contact. The semi-structured instrument addressed ten topics consisting of multi-part questions about a participant's background and perception of the firm, career aspirations, work performance, recognition, work relationships (upward and/or downward), and work-life considerations. Our instrument was specifically developed with generational workforce challenges in mind and therefore we adapted the instrument based on each participant's background (mainly, for exec-, mid-, and juniorlevels). We used clarified responses with follow-up questions, adjusting interview questions 
based on the participant's responses, where necessary.

\section{Data Collection}

We conducted interviews with 26 practicing accounting professionals from six (of ten) offices of a national accounting firm. To accommodate our preference for face-to-face discussion, interviews took place either at the researchers' offices or at two offices of the firm to keep travel costs low and ensure convenience for participants. To select participants, we reviewed a breakdown of the number of personnel at different levels and titles in each office. We also examined job descriptions of the different levels and titles in order to understand job responsibilities and the minimum number of years spent at each level. ${ }^{6}$

We selected participants from six offices, which are the offices with a larger number of personnel. We verified with our executive-level firm contact that these six offices capture a substantial base of personnel and that these offices adequately represent the firm's professional activities. For each office selected, we obtained the names of all personnel in that office and then determined the size of our sample from each office in proportion to the relative size of the office. Within our office-level selection, we identified an approximately equal number of participants at each level/title to ensure an adequate overall number of participants at each level/title. We also selected an approximately equal number of female and male participants. We selected a total of 35 potential participants. Then, the executive-level firm contact emailed the potential participants to introduce the study, to grant permission to participate in the interview process, to encourage participation, and to inform potential participants that the researchers will contact them

\footnotetext{
${ }^{6}$ Firm personnel follow the following progression from level-to-level (minimum years at each level): Staff I (1); Staff II (1); Senior Accountant (1); Supervisor (2); Manager (2); Senior Manager (2); Principal or Partner (nonpartner principals, partners without [non-directors] and with [directors] ownership in the firm). Principals are described as generally personnel with more experience than senior managers, but who are not likely going to make partner.
} 
thereafter. Then, we contacted the potential participants directly to arrange the interviews.

Twenty-six of the 35 potential participants (approximately 75 percent) accepted an interview between May and June 2018. Thirty-eight (62) percent of our final sample were male (female). ${ }^{7}$ Participants had mixed experience in audit and tax. ${ }^{8}$ This allows us to speak broadly to accounting professionals rather than to a specific service line (e.g. audit or tax). We grouped the 26 participants into three broad hierarchical levels: junior (staff to supervisor), mid- (manager to senior manager), and exec-level (executive management, director and non-director partners, principals). Our grouping is based on the firm's description of job responsibilities at each level and distinguishes the extent to which personnel are responsible for leading engagements, and exhibiting leadership in business development and administration of the firm/practice. We do not claim that the different levels align perfectly with anecdotal generational age divisions. However, our hierarchical levels still allow us to speak to generational differences because of the inherent age and generational differences across levels. Further, the more senior levels clearly express in the interviews that they are from a different generation compared to the junior-level.

The distribution of interviews ranges from seven to ten in each level. Interviewing an evenly distributed number of personnel in each level was important for three reasons. First, we were able to understand aspects of socialization at different levels. Second, we were able to witness how attitudes and behaviors towards work hours are reflected in each level. Third, we can make comparisons between the perspectives of different levels and each level's perspective of the other levels. We report firm and participant demographics in Table 1.

\footnotetext{
${ }^{7}$ The gender distribution of all professional personnel within the accounting firm is 41 percent female and 59 percent male. The executive-level has a gender distribution of 19 percent female and 81 percent male.

${ }^{8}$ We requested information on which area (e.g., audit or tax) each personnel is specialized in; however, the firm is only recently in the process of moving from a generalist system (where personnel do both tax and audit) to a specialized, "niche" system (where personnel are assigned to either tax or audit functions, and are specialized in a limited number of industries). Previously, specialization occurred around the level of manager or senior manager.
} 


\section{[Insert Table 1 here]}

Before the interviews, we provided the participants with an outline of the major goals of the study, an introduction to the research team, and an assurance of confidentiality. Participants offered both positive and negative views on the firm and on different workforce levels, which suggests that their responses were candid. Our 26 interviews ranged from 23 to 69 minutes with an average duration of 55 minutes. Half of the 26 interviews were conducted by one researcher, whereas the other half were conducted by two researchers together. All interviewees gave consent to be recorded by the researchers who took notes to complement the recordings. After each interview, two researchers conferred and evaluated the responses, identifying common topics that arose.

\section{Data Analysis}

All interviews were professionally transcribed after removing identifiable information. During the interview process, we identified generational differences as well as conflicts and tensions around time to be recurring themes in our interviews. As we read the interview transcripts, we recognized these two themes to be even more prominent. Therefore, the initial development of our codes was based on themes emerging from passages in the transcripts that referred to the notion of time. We also noted themes emerging from the passages that suggest time-related commercializing concerns and processes of socialization.

We developed our coding structure from this initial analysis in conjunction with our knowledge of prior research noting that when participants spoke about time they did so in relation to external factors, socializing mechanisms, and related contradictions and/or pressures. For instance, we identified external factors that create time pressures to be related to client and industry concerns and concerns with the market for professional services more broadly. We 
identified socializing mechanisms to include both formal and informal organizational structures. Lastly, we identified expressions of contradictions or pressures related to flexible work arrangements, work-life balance, hours, and profitability targets. Furthermore, we identified that it would be important to code whether participants speak about perceptions of their own behaviors/attitudes or the behaviors/attitudes of personnel at other levels.

Once we established our preliminary coding structure, we selected one interview at each level to test the coding structure. We analyzed transcripts using NVivo to enhance collaboration in data analysis. We divided the codes among the researchers and each researcher independently coded the three interviews for his/her assigned codes, after which the researchers met to discuss refinement of the initial coding structure. After refining the coding structure, we selected two additional interviews and the researchers independently coded a total of five (20 percent) of the 26 files, with two coders for every code to calculate intercoder reliability. The coding comparison across the five interviews resulted in an average intercoder reliability of 93.5 percent for all codes, with all intercoder reliabilities for an individual code being over $85 \%$. We divided the remaining 21 interviews among the three researchers, each coding seven interviews comprised of participants from all three levels. Once complete, we reviewed each other's coding and then identified exemplars that are representative of each code, with the quotes selected for inclusions in the paper reviewed and approved by all authors. We include additional representative quotes supporting our analysis in Table 2.

\section{Insert Table 2 here}

Both the in-text and representative quotes identify the hierarchical level and reflect both our coding structure as well as our understanding of that structure within the relational model of Smets and Jarzabkowski (2013). We use this model as a framework to help us to understand how 
logics held by different hierarchical levels contribute to the institutional complexity faced by accounting firms and how firms respond with possible solutions.

\section{INSTITUTIONAL COMPLEXITY ACROSS HIERACHICAL LEVELS}

Institutional complexity in our setting is reflected by emerging tensions and conflicts between a firm-level logic and workforce-level logics (attitudes and behaviors) affecting day-today operations and practices around work hours, as captured in the following quote:

Mainly we get criticism on our hours driven theory from the bottom [juniors]. What normally happens is after a couple years they just get used to that ... Our five year plus people ... [they] don't fight it. It's an hours-driven profession. We do budgets based on hours, billing rates. But it is a struggle with the [junior-level] staff... We are having a harder time. Our utilization is going down year over year for an average person. Ten years ago when someone started ... they would be budgeted [targeted] for 1,800 [hours annually] ... but we'd get about 1,900 hours from them. Now, that same group, if we get 1,800 [hours] we're lucky ... So, we're getting less out of the same people. (Exec04) ${ }^{9}$

This quote reflects the idea that the firm now experiences more difficulty in socializing juniors to behave in accordance with the firm's logic around work hours. We observe the exec-level as embodying the commercial logic of the firm and responding to workforce-level logic of juniors. By contrast, mid-level personnel acknowledge the firm-level commercial logic, which they either consider to be imposed by the exec-level or that they have partially bought into because they have been socialized towards being a partner, but question the firm-level logic at the same time.

\section{Recognizing Institutional Complexity: Conflicts in Perspectives on Work Hours}

The first cycle of the Smets and Jarzabkowski (2013) relational model of institutional complexity entails actors recognizing that alternative perspectives exist and create tensions and

\footnotetext{
${ }^{9}$ References refer to the anonymous interviewee and the hierarchical level to which they are assigned. Select language has been omitted or edited from quotes in order to maintain the anonymity of the participant, for the sake of brevity, and to adjust for repetition and colloquialisms (e.g., like, you know, uh, yeah, I mean, so, just, etc). Other language indicated between brackets [], has been amended or added to ensure clarity of the participant's response to the interview questions. The same approach applies to the illustrative examples provided in Table 2.
} 
conflicts with established perspectives. Participants highlight two themes related to tensions and conflicts around work hours. The first theme relates to perceived decreases in the number of billable hours worked by juniors while the second relates to perceived decreases in the efficiency of juniors during the hours worked. Accounting firms track utilization, hours billable to clients as compared to non-billable hours for activities such as business development, training and education, or administration. Billable hours are one of the most important metrics for accounting firms to measure annual performance. Accounting firms also track realization - billable hours charged to a client engagement as compared to the hours budgeted for each engagement - a quantitative measure of efficiency encouraging fewer over-budgeted hours on each engagement. When exec-level personnel speak about attitudes and behaviors around long work hours the tension is primarily related to juniors' utilization, e.g. not "working hard" enough in terms of the requisite billable hours, and realization, e.g. not "working smart" enough in terms of billing too many hours compared to budget. Both mid- and exec-level personnel observe that juniors are resistant to putting in the long work hours traditionally expected by the firm.

Our model is built around our billable hours, that's how we bill our clients, and we see the billable hours are coming down and we have to look for different ways to motivate people to work harder and smarter. It doesn't have to be so much longer as much as smarter, have a better utilization ... I don't like to use the word Millennials, but there's this vibe they ... don't want to put the work in. We're working through that right now just trying to figure out ways to motivate them to work harder and smarter. (Exec01)

However, mid- and exec-level personnel concede that the firm-level commercial logic demands firm personnel to do more in a shorter period of time and from an earlier point in one's career.

Our staff are coming in at a higher level of knowledge than I had [when I was at their level] ... While it may have taken 10 years of experience to get to one level, now we can do that in 3 or 5 years. That's the big change and it's all driven by technology, ... [and] the market look[ing] at an audit as a commodity. ... That's just one of the rules of working in a commodity business: you need to be ... more efficient and so that is really what's changing the 
engagement with our staff people, we actually need to move a lot quicker. (Exec02)

These quotes express how, for the mid- and exec-level personnel, the expectation driven by a firm-level commercial logic, is that juniors work both harder (i.e., more hours) and smarter (i.e., more efficiently) to maintain or improve the level of utilization and realization.

The juniors also acknowledge the tension around putting in more time and doing the work in less time than budgeted, as in "They [juniors] want to be as efficient in their work as possible, so they can get in and get out. They don't want to be in their desks for 250 hours in May." (Junior05) In contrast to the expectations of mid- and exec-level personnel that juniors work both harder and smarter, mid- and exec-level personnel accurately perceive that the juniors' logic around hours suggest that working harder and smarter are substitutes in the sense that they expect that working more efficiently should translate into fewer overall work hours, not more.

They're [juniors are] not seeking out additional work if their job's finishing up quicker than originally scheduled. They might be like, 'I was scheduled on this job for 55 hours; I got it done in 48; I don't need to fill those 7 other hours'... There's some generational stuff there ... some of the older partners are like, "Well, if I finished things earlier, I couldn't leave until my boss left, so I was obviously looking for work." And now... the generations are a little different, they work more efficiently - and that's kind of a balance between efficiency and getting more hours in. (Mid08)

Thus, juniors' logic of efficiency positively affects realization but reduces utilization. This preference for more efficient hours at work is due to a desire for work-life balance by juniors.

The younger staff are very motivated by work-life balance. They don't want to be here 65 hours a week during tax season; they don't want to be here late on Fridays; they want to be out of here by 5.... We have our busy times of year, and we put up those hours so we can enjoy life outside of that time. (Junior05)

Despite the logic of efficiency conveyed by juniors, the mid- and exec-level personnel do not necessarily perceive the hours worked by juniors to be efficient or effective. This perception of mid- and exec-level personnel reflects the second expression of tension and conflict around 
work hours. In other words, mid- and exec-level personnel not only perceive juniors as wanting to put in fewer billable hours, but they also perceive juniors as not working better, or smarter, when juniors are putting in billable hours. For instance, both the mid- and exec-level personnel express that juniors are disinterested in excelling in a project and seeing the project through to completion, often speaking in terms of the lack of "ownership" exhibited by juniors.

I think what happens is they [juniors] feel like 'okay, I'm given a task, I do it, and then I'm done'... it's hard to get them to feel like it's their own little project ... It's a very different work ethic. It's like they come to work; they do what they're told ... and they just go home and they don't think about it anymore. ... if you were more attentive to the work or what you were doing, there's where the ownership would start to take effect. (Exec05)

My work ethic is ... do what you have to do to get it done, and the younger staff - I hate to say that because I don't feel like there's that big of an age gap - don't think the same way. It's tough to try to get things done when they are like, "It's 5:30 so I'm leaving; my day's over", but clients are still there, deadlines are still there, so finding ... the assistance to get things done is very tough. (Mid05)

As juniors' work attitudes and behaviors eventually affect the work hours and load of the mid-

level personnel, and potentially the realization of the overall client engagement, the mid-level

personnel are particularly focused on tensions surrounding juniors not taking "ownership" and lacking initiative in undertaking more work to reduce the workload of others.

It's a willingness to show you're interested and asking before I shut down for the day, 'Can I help you with something?' ... That's probably the difference that I would see between where I was 10 years ago and where they're [juniors] at today ... they're ok turning down at 5:30 and leaving unless someone went up to them and said 'Can you do this for me.' There's not the drive and motivation where [juniors will think], 'It's the middle of February, the middle of busy season, I'm sure there's a lot of people who have a lot of work to do, let me ask them can I help you with anything?' But in the back of their minds they're saying, "Well if I do that, and someone tells me that they have work to do, now I have to stay for another 2-3 hours'. (Mid01)

Surprisingly, certain juniors indicate that mid- and exec-level perspectives on juniors' efficiency during working hours are appropriately perceived, as in: 
Some of them [juniors] are not capable of doing better; ... they are distracted, and so they make silly mistakes that you have to fix, or get them to fix, which makes the whole thing more inefficient. You could tell them the same thing over and over again, but sometimes it doesn't work ... then there are others who are good ... But more people, I would say, are distracted. (Junior08)

\section{Synthesis Relative to a Relational Model of Institutional Complexity}

Our analysis reveals tensions and conflicts between the logic around work hours held by juniors, and the logic around hours held by the mid- and exec-level personnel. As suggested by Smets and Jarzabkowski (2013), tension is evidenced by a lack of mutual acceptance of the attitudes and behaviors of other levels. This lack of mutual acceptance is expressed as newly presented alternatives being in conflict with "relics of ... the old story" (Smets and Jarzabkowski 2013: 1290) where, for example, mid- and exec-level personnel contrast the attitudes and behaviors of juniors with their own experience at that level. Those comparisons, while making the mid- and exec-level personnel conscious of an alternative way of doing things, lead to execlevel expressions of why their own attitudes and behaviors are appropriate and should be continued. Exec-level personnel legitimize their attitudes by referencing the permanency of the profession's hours-dependent business model.

I say to them [juniors] at every staff meeting, "The industry is not going to change. ... It's labor intensive, it's time compression, date due compression ...it is how you adapt to it ... When you get married, you have to tell your wife you will become a CPA widow. You are not going to be around for a while. When you have kids, you have to tell them that you are not going to be around for a while because of the commitment [to the job]. You tell them [juniors] it is not going to change, you just have to accept it, not fight it. (Exec04)

Juniors, however, do not accept the premise that working both harder and smarter is possible, or even desirable. Instead, juniors speak about the difficulty of being efficient for the duration of an extended workday, the negative impact of long work hours on work quality, and the idea that efficiency should not be penalized any more than working "crazy" hours should be rewarded. 
When people are here for 12-13 hours a day, six days a week, four months a year, you're not functioning efficiently. I don't believe anybody has the capacity to work efficiently and actually bring value to something by doing that many hours continuously ... so being in the office and the kind of hours some of them put in, I really don't believe they're efficient. If they did an efficient job, they should be able to get it done much sooner, and also the quality of work suffers - unless you are doing something very mechanical, unthinkingly ... but if you actually are applying yourself, I don't think it's possible. (Junior08)

Although some mid- and exec-level personnel express that certain entrants are committed to the firm logic, they suggest that there are simply not enough of them compared to prior cohorts and express frustration at the inability to socialize more entrants into the firm's logic around work hours. Where different hierarchical levels maintain separate logics, "polarization" worsens as each level stand their ground and dismiss the logic held by the other level as untenable. Smets and Jarzabkowski (2013) suggest that polarization is problematic in settings where actors are required to collaborate. In such a setting, actors must think beyond, and be critical of, their own attitudes and behaviors, with institutional complexity triggering a process of disruption and possibly reconstruction of logics at different levels.

\section{Disrupting Logics Around Work Hours: Initial Responses to Institutional Complexity}

The second cycle of a relational model of institutional complexity describes how consistent polarization lends to further entrenchment of actors in their own logics wherein actors take deliberate actions to defend their own logics in the face of alternative logics that cannot be dismissed (Smets and Jarzabkowski 2013). This involves "legitimating it [a logic] discursively ..., whilst more actively trying to disrupt the other by calling into question its validity" (Smets and Jarzabkowski 2013, 1299). Exec-level personnel highlight two deliberate means of becoming further entrenched in and trying to entrench others in their ways of doing things. The first means is employing a discourse of rationalizing long work hours by emphasizing the 
benefits that arise to juniors from working long hours and deemphasizing the mandatory nature of long work hours. The second means is one of encouraging social comparisons to the work attitudes and behaviors of others, particularly of high performers, legitimating long work hours as model work behavior.

For instance, exec-level personnel actively reframe the firm logic around work long hours as a means by which juniors can learn more and take advantage of advancement opportunities. This reframing also more positively casts the norms around long hours as persuasive rather than coercive, as the exec-level attempts to persuade juniors to voluntarily increase their work hours because long work hours are personally beneficial to the juniors.

We're saying [to juniors] that the people that work more hours are getting more experience, so somebody who works 2,000 hours versus somebody that's working 1,600 hours, that person over here has gotten over 400 hours more of experience than this person, so you would think they're probably going to rise a little faster ... We're trying to encourage it, we're not saying you have to put in 3,000 hours ... but we're trying to get people to see the value in working a little harder, so they get more experience to advance. (Exec01)

Furthermore, the firm deliberately releases monthly data on the employees with the highest number of billable hours. Exec-level personnel identify with this firm-level practice and use the personal pronoun "we" when speaking about the initiative, illustrating that they adopt the firmlevel logic. This practice is a deliberate action to legitimize and entrench long work hours that is framed by exec-level personnel as helping the juniors benchmark whether they are working hard enough based on whether they behave in a "model" way, one that aligns with the firm's logic regarding long work hours. As one partner expresses:

One thing we tried to do, hoping it would send the right message, monthly we started sending out the top xx productive hours - the top xx people in the firm who had the top billable hours for that month... Initially it was ok. The intent of the email was to tell people, if you are basing your decision that you are working hard on your hours, what's your intel? Your intel should be 'What is 
my peer group doing?' ... [we got] some negative feedback, that ... all we are worried about are hours, hours, hours. We added some message to it as to why, what we were trying to do ... to convey that if they are putting in additional time, they are going to learn more and do well because of that. (Exec04)

Thus, exec-level personnel actively attempt to convince juniors that their attitudes and behaviors are inappropriate by suggesting that if they don't work more hours, they will not learn as much or have the same opportunities as their colleagues who do work long hours.

Indeed, some juniors accept the framing of work hours as an opportunity for learning and advancement and some observe the behavior of colleagues as a sign of what is expected of them.

The more you learn at your base level, the better it is because let's say, ten years from now, somebody's a manager, there will be ten years' worth of expectation from you - that you have been here for ten years; you should know this, this and this. ... I don't want to be, in two years from now, people are expecting, 'okay, she has been here for 2 1/2 years, she should know this, this and this', and I didn't invest my own time to learn that, and then that's going to reflect bad on the future me. (Junior06)

However, more commonly, juniors exhibit defensiveness, maintaining their attitudes and behaviors around work hours. For instance, juniors express the limits to and even the negative perception of the firm-level rationalization around working long hours, particularly as a comparative means by which to assess their work behaviors.

One initiative that has received a lot of backlash when trying to motivate younger staff: our CEO every month sends out a charge hour email ... with [top xx people with] charge hours for the previous month ... but I don't necessarily think that recognition and killing it on charge hours is what's going to motivate the younger staff. They don't want to work 200 hours a month so saying, 'Oh, here's 20 people that DID work 250 hours' why would that motivate me? (Junior05)

The above quote indicates that, like the exec-level personnel, the juniors are entrenched in their established attitudes and behaviors, evaluating the firm-level logic as wrong even when framed as a means for learning and opportunity, and asserting their own attitudes and behaviors as right 
(Smets and Jarzabkowski 2013). Both firm- and workforce-level logics are defended while suggesting the alternative logics are not appropriate or legitimate ways of behaving.

\section{Synthesis Relative to a Relational Model of Institutional Complexity}

Our analysis aligns with the second cycle of Smets and Jarzabkowski’s (2013) relational model of institutional complexity whereby different hierarchical levels experience repeated confrontation with different logics. In that confrontation, actors evaluate their own logics relative to those of others, casting the attitudes and behaviors of others as inappropriate and legitimating their own attitudes and behaviors as more acceptable. In defending the firm- or workforce-level logics against the alternative, institutional complexity persists. The Smets and Jarzabkowski (2013) model suggests that the presence of persistent complexity has the potential to produce a "work-level crisis" as threats to established ways of working become harder to dismiss. As the contradiction becomes more prominent and (possibly) generates negative effects, actors reflect on the defense of their attitudes and behaviors and reconsider the appropriateness of that defense.

For instance, mid-level personnel start to question the reasonableness of exec-level rationales.

If you get somebody who works on a job that requires a lot of billable hours, you shouldn't penalize somebody [else] ... if they didn't have that many billable hours because they didn't work on those type of projects. It's not really fair. You're not comparing apples to apples. Now, if everybody has an equal amount of work, and this other person chose to work harder than the other person, then that's a fair assessment. ... I don't blame [people who did not get assigned to jobs with high billable hours] for getting annoyed because that makes [them] feel like, 'What, am I not doing a job because I don't have the billable hours? Is it all about billable hours?', it really shouldn't be. (Mid02)

This is reminiscent of the idea that actors at the intersection of overlapping institutional domains (e.g. the mid-level personnel) may experience tensions more vividly and therefore are likely to be more reflexive about both sets of logics. Therefore, even though the mid-level personnel are trained and socialized towards the exec-level, they understand the tensions between the firm- 
logic and the work perspective of juniors.

Deliberate firm-level attempts to reframe working harder and smarter as a benefit and motivating factor for the juniors also seem to exacerbate contradictions between the idea of working harder and smarter for the mid-level personnel.

You have leadership that's telling you need to have $x$ number of hours per week ... and you have somebody who ... is telling you [that] you have a budget [that you should not exceed]. When the two do not reconcile, what do you do? ... Do you want to have the conversation about me blowing the budget, or do you want to have the conversation about me not having the charge hours that you're mandating for me? ... because, my bill rate, if I were to meet the charge hour goals based on the clients that we have, I would blow all the budget ... It's a simple equation ... for whatever reason, they [exec-level] can't see it. (Mid03)

While the above quote implies that exec-level personnel are unwilling to acknowledge that their goals of increasing both utilization (i.e., work harder) and realization (i.e., work smarter) may be conflicting, the exec-level personnel do raise questions of whether there are ways of reframing the firm logic around work hours in a manner that is more consistent with the logic held by juniors. This reflection and evaluation of logics aligns with the "practical-evaluative" dimension suggested by the second cycle of Smets and Jarzabkowski’s (2013) model, as in:

We are struggling conceptually, how to change [our business structure] to any other way than the billable hours ... You are hearing, we shouldn't be an hours-driven profession, we should be a project, job driven profession. We get it, it makes sense. We are having a hard time still trying to figure out then, how do we evaluate our profitability without putting the hours component back in. How do we manage people better by telling them we need them to do these three jobs versus telling them we need you to work 60 hours this week, 40 hours next week, and 50 hours this week? We are still battling with that, trying to find a way to motivate the staff to get the work done. There's always too much work to be done in a short period of time. Unfortunately, with the compression of this industry ... [There's] not much choice... it's just how it is. (Exec04)

The exec-level acknowledges the persistence of institutional complexity, but their 
attitudes are ambiguous in terms of whether the complexity needs to be or can be resolved, or that it is just "the nature of the business". In the absence of pressures that create a "work-level crisis" of sufficient magnitude to overcome entrenchment, an organization may remain in cycle 2 for a long time, with the institutional complexity continually at war. Or, polarization might generate enough frustration or a "work-level crisis" of sufficient magnitude to compel the organization to reduce the institutional complexity. The third cycle of Smets and Jarzabkowski's (2013) relational model suggests that when persistent and increasing tensions and conflicts do not meet organizational objectives and expectations, the organization will reach a point where they will consider ways to reduce the institutional complexity.

\section{Reconstructing Logics Around Work Hours: Further Responses to Institutional Complexity}

The third cycle of Smets and Jarzabkowski's (2013) relational model helps us to understand how responses to institutional complexity involve reducing the tensions experienced through adaptations that overcome entrenchment and precipitate mutual adjustment of attitudes and behaviors. Adaptations focus on reconstructing what is previously experienced as contradictory in a way that is now compatible. This suggests that firms may try adapting or reframing the firm-level commercial logic around work hours in a way that integrates them with the work perspectives of juniors. This integration of attitudes and behaviors may result in what Smets and Jarzabowski (2013) call an expanded practice repertoire, comprising aspects of the traditional logic and the alternative perspective. As the exec-level personnel begin to better understand the source of tensions, the exec-level experiments with and reconstructs practices around work hours in relation to, rather than opposition to, the alternative view. This entails experimentation with flexible work arrangements that aim to satisfy the firm's requirement to 
work long hours with the ability to choose when and where those hours are worked. This also involves the reframing of work hours as somehow integrated with non-work hours.

Our exec-level indicates that juniors' perspectives on work hours drive experimentation around flexible work arrangements such as flex-time and work-at-home arrangements. For example, the exec-level expresses how the firm offers various formal and informal flexibility arrangements for its personnel, with one participant noting "it's very flexible here. We treat everybody as a professional as long as we know you're getting your work done” (Exec01). In this way, flexibility is a means by which firm personnel can reconcile the long hours required to get their work done around non-work obligations.

[The office managing partner] is not sitting there saying 'Everybody better be here by 8:00 on Saturday and stay 'til 5:00'. ... Other offices dictate busy season hours..., we've gotten away from that ... and people really appreciate that because, let's say they had kids that were playing sports on Saturday but they could come in all day Sunday without interrupting their family ... [He] was like, 'I don't care when you come. As long as you get your work done it's fine' ... that type of respect and flexibility was really important. (Exec06)

The importance of flexibility as a means to make the firm-level logic of long work hours compatible with the workforce-level logic of working efficiently and having work-life balance was echoed by both the mid- and junior-level personnel. Interestingly, these flexible work arrangements are portrayed by personnel who used them as mechanisms that make their life outside of work easier so that they can reinvest time savings into work.

I've always used [flex-time] ... I am an early morning person, so I could get in, seven in the morning, and go home at four ... even if you wanted to take a half a day, you can work two hours extra, two days during the week ... now I work from home when I can, which just makes it easier. It saves time. Even a little commute to work, it saves time. I could drop my kids off at daycare, go home and work, go get 'em, and it's like I gained an hour on the day ... that's good and most people are understanding to that. It's getting better and better, but the idea of people working from home at my level, it's not that big of a deal. (Mid02) 
I could leave early on a Friday, and no one's going to question it and say I'm not working hard because they ... know that I'm getting my stuff done ... That's the thing I like here is, if you're getting your stuff done, no one's bothering you. It's hard to get your stuff done and leave early or do whatever, but if you have a night where you need to be somewhere, no one's ever going to argue with you. If you have a Saturday that you can't be in the office, no one's ever really going to argue it. [Even if you are] Not even meeting chargeable hours. In general, if I'm on a job with this manager, and they know my stuff's getting done, they're not going to really mind if I'm, on a Friday, leaving at 2:00. (Junior09)

Critically, all levels cast alternative work attitudes and behaviors as acceptable within the confines of ultimately being able to "get the work done". The implication being that while firmlevel expectations around working harder and smarter remain; an individual is afforded more agency to determine the way those expectations are met. In this way, all levels try to reconstruct "contradictory" logics as "compatible" (Smets and Jarzabowski 2013).

By experimenting with flexible work arrangements, the exec-level suggests that firm logics around working more hours are compatible with, rather than conflicting with workforcelevel logics around working more efficiently and having work-life balance. However, in line with Smets and Jarzabkowski (2013), that compatibility does not mean full alignment with the alternative perspective but rather that the expanded practice repertoire may accommodate the alternative view. Indeed, flexible work arrangements do not produce full alignment between firm and workforce attitudes and behaviors across all levels. The lack of alignment is indicated both in terms of how the junior level is not ready for flexibility as well as in terms of how more senior levels need to adjust their attitudes in order to further reduce tensions around hours.

For instance, the mid- and exec-level personnel describe how flex-time was initially offered to first-year juniors but taken away until juniors reach their third year at the firm due to a perception of misuse or misunderstanding of appropriate flex-time behavior. 
The first years did [have flex-time] last year, which I knew was going to be interesting ... We tried to help guide them ... and for some it worked out fine, but others at 4:00 they were just leaving. I'm not really sure how they made up their hours ... But I thought they have never been in that environment where they're expected - where you have to even work 40 hours. Most of them were fresh out of school; they didn't know, so it was like, 'Oh, we just started; we're working with a great firm; we have flex-time; no minimum hours during busy season; no mandatory Saturdays'. They think they got the greatest job, ever ... but they weren't getting the fact that the work still needed to be done. (Mid05)

On the other hand, participants suggest that certain exec-level personnel have difficulties letting go of the way things used to be when they came up through the firm ranks and hold on to traditional expectations about work hours.

In my [performance] review, one of the comments with the managing partner was 'sometimes when you're working from home, it's hard for me to reach [you]' ... I said, 'when has it ever been difficult for me to be reached because, if I'm working, I'm always on skype. Even if I'm [not] on Skype and say I'm having to run this errand', I return emails immediately. Even if I'm on vacation, you get an email returned within 24 hours'. I said, "Is it because you're walking down to my office and I'm not there?" He's like, 'I just don't want to bother somebody when they're off', and I'm like, 'well, I'm not off' ... there's another older partner here who ... gave me an amazing review last year yet said, "but she seems to have a lot of outside things that she has to take care of". (Mid07)

Building on this, personnel at all levels acknowledge that, despite more discretion over work hours and location, there are still mixed messages around that discretion. Juniors suggest that flexibility around work hours and location is improving; however, they struggle with decisions about when it is appropriate to exercise discretion and when it is not.

Some offices [are] better than others at understanding the lack of importance of being in the office some days where you could be home ... maybe on a Memorial Day Friday, if I don't take it off, I can be efficient at home, and if I'm not working with anyone that requires talking to them in person, it shouldn't be taboo for me to be home. ... But I've heard about it from other staff, and I can see their tension when it's a Friday at 4:00 and they want to leave a little early in the summer [but they are afraid to do so] ...Where they're not even doing any work; they're just staring at the clock. (Junior09) 
By contrast, the mid-level personnel struggle not with when to exercise discretion around work

hours and location, but with the encroachment of work into their non-work time. For example,

You're always expected to be on the clock. I went [on vacation] and I did not bring my computer ... because I did not want to be distracted or feel the obligation to log on while I was away. I had to borrow a computer while I was there ... because something couldn't wait ... so that's a struggle, and I don't know how we fix that ... I don't know how to break that, personally, but I also think it's firm wide not just on a personal level. Now, we're doing skype calls. 'We'll always be able to find you', they said. 'You'll always have a phone', and I don't know that I always want to have a phone ... but I feel like that it's somewhat of the mentality, which is tough to break. (Mid05)

While some mid-level personnel reflect on the incompatibility of having work hours

integrated with non-work hours, many more mid- and exec-level personnel frame their working hours as integrated into, and compatible with, their non-work hours.

I choose currently to work a lot of hours. I probably work 60-70 hours week but I enjoy it ... my life and job have become integrated ... I have [remove number] children and I never missed a game, a graduation ... Even when ... we didn't have email yet, I would ... pack up my car with a bunch of files, leave the office at 3 o'clock ... go home and get my kids ready. I'd take them to the game, finish around 7 o'clock we'd go home and have dinner together and they'll be taking baths and I'll be opening up the files. I had the flexibility to work when I wanted to work ... it's even more flexible with technology because you can literally work any place you can get an Internet connection ... so I never go into the office or schedule an appointment on a Friday during the summer, but between Friday, Saturday, and Sunday I will put in 8 hours of work cause I'll get up early, I'll respond to emails, I'll do a phone call, I'll deal with some things. (Exec02)

The exec-level presumes the integration of work and non-work hours by other levels, especially those closer to the exec-level. Importantly, although the firm offers flexibility to its personnel, it also expects its more senior personnel to reciprocate with flexibility in the form of being available for work during non-work hours, as noted in the quote below:

I expect them [mid-level personnel] to be very flexible ... if I have to call them at 10:00 at night, unfortunately, they will answer because they know, if it's a project and it's of urgency, that they have a commitment [to be] available, even on a weekend ... It has a life effect when you're at a higher level and 
you're on a significant engagement or there's issues. I expect probably way too much, but it's nothing I don't expect of myself. I think that they're all - at that level, they're bought in, they get it. They understand that that's the expectation, and they've already adopted that philosophy. (Exec07)

Furthermore, the mid-level expresses how exec-level expectations around work hours are integrated into their lives either by their imposition and/or because the mid-level, being trained and socialized towards partner, internalize these expectations as they rise through the ranks. The contradiction where the mid-level is concurrently expressing both voluntary adoption of long work hours indicative of internalizing the firm-level logic and a lack of volition over long work hours due to external expectations is particularly evident in this quote:

I work all the time, and that's expected ... I'm always on, in the sense that I can get a call on the weekend, I can get an email on the weekend, and I will respond if I choose to - again, if I choose to - or because it's non-business hours, but I'll choose respond to it because that's just the type of person I am and that's the kind of rapport I want to have with my client or with my superiors ... If I want to, I can walk out of the office at 3:00 in the afternoon... I can show up at 10:00 in the morning. To me, that's one of the big benefits of public accounting ... Now, I'm not going to do that every day ... but I can do that, and there isn't anyone who's going to say, "Well, what are you doing?" (Mid03)

\section{Synthesis Relative to a Relational Model of Institutional Complexity}

The third cycle of Smets and Jarzabkowski's (2013) relational model suggests that in the absence of formal templates, institutional complexity may be managed through experimentation with and reconstruction of practices. This experimentation and reconstruction do not involve plans of grand institutional design but rather improvisations that recast the tensions and conflicts between logics as compatible rather than contradictory by maintaining some attitudes and behaviors and transforming others (Smets et al. 2012). According to Smets and Jarzabkowski (2013), this recasting of logics can produce an expanded practice repertoire that becomes acceptable to both sides as the practice is perceived as more of a shared solution than one that is 
imposed, at least in the sense of having some discretion over one's individual behavior.

For instance, our participants discuss how flexible work arrangements allow the tailoring of experiences to individual needs.

I have one guy who values his leisure time more than anything else. We find a way to put him on engagements so he can have a little bit more flexibility, where he can work remotely, where he doesn't have to be in the office all the time with somebody sitting next to him, to get the work done. It's understanding who they are, how they operate, and what gets them to go. (Mid03)

It comes into play, your personality, then it comes into play, what is your own work ethic? On top of that, everybody's family situation is different ... [Before] coming here, I heard now accounting firms are getting a little bit more flexible, since we have tools of working more and everything, which is good, but [the approach to work hours] is personal preference. If I want to sit here, finish the work and then go home, that's fine. You want to take work home, that's fine too, as long work gets done. (Junior06)

With the idea of tailoring individual work hour experiences, the management of institutional complexity around how to get the juniors to work harder and smarter to "get the work done" involves adaptations on both sides. Through these adaptations, the conflict between the firmlevel commercial logic and perspective of the juniors is reduced, even if not completely aligned.

This implies, in our setting, the absence of the fourth cycle of the relational model of institutional complexity. The fourth cycle of the model suggests a cycle during which perceptions of alternative logics move from being perceived as compatible to being perceived as complementary. For complementarity to be perceived, the expanded practice repertoire must be experienced as more than a fragile improvisation of the firm. Rather, the fourth cycle involves formally consolidating the expanded practice repertoire, i.e. work hour/location flexibility, into firm structures and routines. Considering that the earliest entrants to the firm are not afforded flex-time and that late juniors as well as the mid- and exec-levels still struggle with flexibility as 
the normalized order of working, full complementarity between firm-level and workforce-level logics around working harder and smarter hours has not yet been achieved.

\section{DISCUSSION AND CONCLUSION}

This paper presents the results of a field study to understand how firms and their workforce respond to potential tensions and conflicts arising from different work attitudes and behaviors across hierarchical levels. We mobilize a relational model of institutional complexity (Smets and Jarzabkowski 2013) to appreciate tensions and conflicts between competing firmand workforce-level attitudes and behaviors (logics) particularly around work hours in the accounting profession. The model helps us to identify the polarization of different firm- and workforce-level logics on work hours and the potential for polarization to become a "work-level crisis", disruptive to firm practice as well as to the experiences of firm personnel. The model then helps us to understand how, in order to deal with this "work-level crisis", an expanded practice repertoire around flexible work arrangements emerges that suggests compatibility between the firm- and workforce-level logics.

Our work supports the implication of Smets and Jarzabkoswki (2013) that organizations (accounting firms) and inhabited actors (professional workforce) may remain "stuck" in one cycle of the model. In our case, the firm rests in the third cycle where they have reconstructed the flexibility around long hours as compatible with younger generations' attitudes and behaviors. However, it remains to be seen whether flexible work practices address the underlying experience of contradiction in the long-term or represent an improvisation that simply shifts the disruption to a future period. Indeed, our data hints that tensions and conflicts relate not only to the number of work hours but the nature of the work itself that needs to be reconciled between the firm and recent entrants to the workforce. As such, practices that allow for flexibility around work hours and location may address only one aspect of complexity and only temporarily. Future 
research can mobilize the model to study how this expanded practice repertoire around flexibility evolves as well as other instantiations of institutional complexity between organizations (accounting firms) and their inhabited actors and the responses to complexity that transpire.

Overall, this study contributes to the accounting literature by enriching our understanding of accounting firm's challenges with socializing recent entrants into accepting the norms of long work hours. In doing so, we highlight differences between firm- and workforce-level perspectives around work hours and the firm's responses to and possibilities for bridging the differences. We provide rich accounts of the interactions and exchanges around work hours across hierarchical levels, which our analyses indicate are closely associated with perceived generational differences. Long work hours are traditionally the norm in accounting firms and are presented in the literature as relatively unquestioned by accounting firm personnel. Notwithstanding employee turnover, prior literature generally presumes that firm personnel come to behave in the manner desired by the accounting firm through organizational mechanisms (Anderson-Gough et al. 2000; Kornberger et al. 2011; Pentland 1993). Our work suggests that organizational mechanisms may need to be adapted considering changing attitudes and behaviors of recent entrants to the workforce and that such adaptations may serve to close the gap between the expectations of the firm and recent entrants and, ultimately, reduce turnover. Future research can examine the effectiveness of adaptations employed by the firm in reducing tensions and conflicts across levels, and the impact of these on work quality as well as turnover. Although our research is important to firms that are trying to understand how to socialize employees from younger generations into working long hours; our research is also important to current and future accounting firm personnel as it may assist them in identifying and reconciling a potential contradiction between their own goals and the goals of the firm. 
Lastly, we contribute to a discussion of relational responses, at both the firm- or execlevel and the workforce-level, that aim to bridge differences and reduce institutional complexity. More can be done to understand institutional complexity around work hours within accounting firms of different sizes (Durocher et al. 2016b; Lander et al. 2013). While evidence supports the generalizability of our observations to the Big Four context (Buchheit et al. 2015), whether and how the Big Four firms and personnel experience tensions and conflicts around work hours, which are longer than those worked in small firms, is an empirical question (Daoust 2019). Comparing and distinguishing between perceptions of work hours and the nature of work in big or small firms may inform research and practice as to accounting professional's recruitment and retention decisions as well as the characteristics of work that engage versus repel the workforce.

Furthermore, more can be done to understand the costs of managing institutional complexity surrounding firm- and workforce-level attitudes and behaviors. For instance, Durocher et al. (2016a) highlight how accounting firms use discourse in their communications highlighting work-life balance programs that align with younger generations' attitudes and behaviors and find evidence that programs in the workplace were modified or initiated to adapt to these attitudes and behaviors. Adaptation to the attitudes and behaviors of recent entrants suggests important, perhaps significant, costs to the firm in terms of revisions to informal and formal organizational mechanisms, including performance evaluation and related incentives. Adaptation may also come with hidden "costs" that affect the ability to effectively develop technical and managerial skills over time as well as relational skills with clients. As the nature of professional work undergoes further technological changes, and the skills and abilities of the professional work force change with it, how and the extent to which firms internalize workforcelevel attitudes and behaviors remains an empirical question that warrants careful consideration. 


\section{REFERENCES}

American Institute of Certified Public Accountants. 2019. Health insurance, paid time off and student loan forgiveness top list of Millennials' desired workplace benefits: AICPA survey. AICPA. Available at: https://www.aicpa.org/press/pressreleases/2019/millennials-desiredworkplace-benefits.html

Anderson-Gough, F., C. Grey, and K. Robson. 2000. In the name of the client: The service ethic in two professional services firms. Human Relations 53 (9): 1151-1174.

Anderson-Gough, F., C. Grey, and K. Robson. 2001. Tests of time: Organizational timereckoning and the making of accountants in two multi-national accounting firms. Accounting, Organizations and Society 26: 99-122.

Buchheit, S., D. W. Dalton, N. L. Harp, and C. W. Hollingsworth. 2016. A contemporary analysis of accounting professionals' work-life balance. Accounting Horizons 30 (1): 41-62.

Carter, C., and C. Spence. 2014. Being a successful professional: An exploration of who makes partner in the Big 4. Contemporary Accounting Research 31 (4): 949-981.

Coffey, A. J. 1994. 'Timing is everything'; Graduate accountants, time, and organizational commitment. Sociology 28 (4): 943-956.

Costanza, D. P., and L. Finkelstein. 2015. Generationally based differences in the workplace: Is there a there there? Industrial and Organizational Psychology 8 (3): 308-323.

Covaleski, M. A., M. W. Dirsmith, J.B. Heian, and S. Samuel. 1998. The calculated and the avowed: Techniques of discipline and struggles over identity in Big Six public accounting firms. Administrative Science Quarterly 43: 293-327.

Daoust, L. 2019. Playing the Big Four recruitment game: The tension between illusion and reflexivity. Critical Perspectives on Accounting. https://doi.org/10.1016/j.cpa.2019.04.002.

Deloitte. 2008. Decoding generational differences: Fact, fiction ... or should we just get back to work?. Available at:

https://public.deloitte.com/media/0507/250608/us_decodinggenerationaldifferences.pdf

Dirsmith, M. W., J. B. Heian, and M. A. Covaleski. 1997. Structure and agency in an institutionalized setting: The application and social transformation of control in the Big Six. Accounting, Organizations and Society 22: 1-17.

Durocher, S., M. Bujaki, and F. Brouard. 2016a. Attracting Millenials: Legitimacy management and bottom-up socialization processes within accounting firms. Critical Perspectives on Accounting 39: 1-24.

Durocher, S., Y. Gendron, C.-F. Picard. 2016b. Waves of global standardization: Small practitioners' resilience and intra-professional fragmentation within the accounting profession. Auditing: A Journal of Practice \& Theory 35 (1): 65-88. 
EY. 2015. Global generations: A global study on work-life challenges across generations. Available at:

https://www.ey.com/Publication/vwLUAssets/Global_generations_study/\$FILE/EY-globalgenerations-a-global-study-on-work-life-challenges-across-generations.pdf

Fogarty, T. J., A. Reinstein, and R. S. Heath. 2017. Are today's young accountants different? An intergenerational comparison of three psychological attributes. Accounting Horizons 31 (2): 83104.

Gendron, Y., R. Suddaby, and H. Lam. 2006. An examination of the ethical commitment of professional accountants to auditor independence. Journal of Business Ethics 64 (2): 169-193.

Greenwood, R., M. Raynard, F. Kodeih, E. R. Micelotta, and M. Lounsbury. 2011. Institutional complexity and organizational responses. Academy of Management Annals 5: 317-71.

Greenwood, R., and R. Suddaby. 2006. Institutional entrepreneurship in mature fields: The Big Five accounting firms. Academy of Management Journal 49 (1): 27-48.

Grey, C. 1998. On being a professional in a big six firm. Accounting, Organizations and Society 23 (5/6): 569-587.

Hirsch, P. M., and Y. S. Bermiss. 2009. Institutional "dirty" work: Preserving institutions through strategic decoupling. In Lawrence T.B., R. Suddaby, and B. Leca (eds), Institutional work: Actors and agency in institutional studies of organizations. Cambridge: Cambridge University Press, 262-283.

Jarzabkowski, P., M. Smets, R. Bednarek, G. Burke, and P. Spee. 2013. Institutional ambidexterity: Leveraging institutional complexity in practice. Research in the Sociology of Organizations 39: 37-61.

Jay, J. 2013. Navigating paradox as a mechanism of change and innovation in hybrid organizations. Academy of Management Journal 56 (1): 137-159.

King, E., L. Finkelstein, C. Thomas, and A. Corrington. 2019. Generational differences at work are small. Thinking they're big effects our behavior. Harvard Business Review. Available at: https://hbr.org/2019/08/generational-differences-at-work-are-small-thinking-theyre-big-affectsour-behavior.

Kornberger, M. L. Justesen, and J. Mouritsen. 2011. "When you make manager, we put a big mountain in front of you": An ethnography of managers in a Big 4 accounting firm. Accounting, Organizations and Society 36: 514-533.

KPMG. 2017. Meet the Millennials: Produced under the umbrella of KPMG's "Its Her Future" Programme. Available at: https://home.kpmg/content/dam/kpmg/uk/pdf/2017/04/Meet-theMillennials-Secured.pdf

Lander, M. W., B. A. S. Koene, and S. N. Linssen. 2013. Committed to professionalism: Organizational responses of mid-tier accounting firms to conflicting institutional logics. Accounting, Organizations and Society 38: 130-148. 
Lupu, I., and L. Empson. 2015. Illusio and overwork: Playing the game in the accounting field. Accounting, Auditing, and Accountability Journal 28 (8): 1310-1340.

Malsch, B., and Y. Gendron. 2013. Re-theorizing change: Institutional experimentation and the struggle for domination in the field of public accounting. Journal of Management Studies 50 (5): 870-899.

Malsch, B., and S. E. Salterio. 2016. "Doing good field research": Assessing the quality of audit field research. Auditing: A Journal of Practice \& Theory 35 (1): 1-22.

McPherson, C. M., and M. Sauder. 2013. Logics in action: Managing institutional complexity in a drug court. Administrative Science Quarterly 58 (2): 165-196.

Meyer, R., and M. Höllerer. 2016. Laying a smoke screen: Ambiguity and neutralization as strategic responses to intra-institutional complexity. Strategic Organization 14 (4): 373-406.

Ng, E. S. W., L. Schweitzer, and S. T. Lyons. 2010. New generation, great expectations: A field study of the millennial generation. Journal of Business and Psychology 25 (2): 281-292.

Oliver, C. 1991. Strategic responses to institutional processes. Academy of Management Review 16 (1): 145- 179.

Pache, A.-C., and F. Santos. 2010. When worlds collide: The internal dynamics of organizational responses to conflicting institutional demands. Academy of Management Review 35: 455-476.

Pache, A.-C., and F. Santos. 2013. Inside the hybrid organization: Selective coupling as a response to competing institutional logics. Academy of Management Journal 56: 972-1001.

Pentland, B. T. 1993. Getting comfortable with the numbers: Auditing and the micro-production of macro-order. Accounting, Organizations, and Society 18 (7/8): 605-620.

Power, M., and Y. Gendron. 2015. Qualitative research in auditing: A methodological roadmap. Auditing: A Journal of Practice \& Theory 34 (2): 147-66.

PricewaterhouseCoopers. 2013. PWC's Next Gen: A global generational study. Evolving talent strategy to match the new workforce reality.

Schneider, A., C. Wickert, and E. Marti. 2017. Reducing complexity by creating complexity: A systems theory perspective on how organizations respond to their environments. Journal of Management Studies 54 (2): 182-208.

Smets, M., and P. Jarzabkowski. 2013. Reconstructing institutional complexity in practice: A relational model of institutional work and complexity. Human Relations 66 (10): 1279-1309.

Smets, M., P. Jarzabkowski, G. T. Burke, and P. Spee. 2015. Reinsurance trading in Lloyd's of London: Balancing conflicting-yet-complementary logics in practice. Academy of Management Journal 58: 932-970.

Smets M., T. Morris, R. Greenwood. 2012. From practice to field: A multi-level model of practice-driven institutional change. Academy of Management Journal 55 (4): 877-904 
Suddaby, R., D. J. Cooper, and R. Greenwood. 2007. Transnational regulation of professional services: Governance dynamics of field level organizational change. Accounting, Organizations and Society 32 (4): 333-362.

Suddaby, R., Y. Gendron, and H. Lam. 2009. The organizational context of professionalism in accounting. Accounting, Organizations and Society 34: 409-427.

Thornton, P. H., and W. Ocasio. 1999. Institutional logics and the historical contingency of power in organizations: Executive succession in the higher education publishing industry. The American Journal of Sociology 105 (3): 1958-1990.

Thornton P. H., W. Ocasio, M. Lounsbury. 2012. The institutional logics perspective: A new approach to culture, structure and process. Oxford: Oxford University Press.

Vermeulen, P. A. M., C. Zietsma, R. Greenwood, and A. Langley. 2016. Strategic responses to institutional complexity. Strategic Organizations 14 (4): 277-286.

Weiner, S. P, and R. Rasch. 2015. Generational differences at work are much ado about very little. IBM Smarter Workforce Initiative. Available at: https://www.ibm.com/downloads/cas/KRQVGDA6.

Zeff, S. A. 2003a. How the U.S. accounting profession got where it is today: Part I. Accounting Horizons 17 (3): 189-205.

Zeff, S. A. 2003b. How the U.S. accounting profession got where it is today: Part II. Accounting Horizons 17 (4): 267-286.

Zietsma, C., and T. B. Lawrence. 2010. Institutional work in the transformation of an organizational field: The interplay of boundary work and practice work. Administrative Science Quarterly 55 (2): 189-22. 
TABLE 1

Interview Details

Panel A: Summary of Interview Details by Hierarchical Level

\begin{tabular}{lccc}
\multicolumn{1}{c}{ Hierarchical Level } & $\begin{array}{c}\text { Number of } \\
\text { Interviews }\end{array}$ & $\begin{array}{c}\text { Gender } \\
\text { F/M }\end{array}$ & $\begin{array}{c}\text { Mean } \\
\text { Length of } \\
\text { Interviews }\end{array}$ \\
\hline $\begin{array}{l}\text { Exec-level [CEO, Partner in } \\
\text { Charge, HR Director, Shareholder] } \\
\begin{array}{l}\text { Mid-level [Senior Manager, } \\
\text { Manager] }\end{array}\end{array}$ & 7 & $5 / 2$ & 64 \\
$\begin{array}{l}\text { Junior-level [Supervisor, Senior Acct, } \\
\text { Staff I/II] }\end{array}$ & $\underline{10}$ & $4 / 5$ & 59 \\
$\quad$ Totals & 26 & $7 / 3$ & $\underline{51}$
\end{tabular}

Panel B: Interview Details by Participant

\begin{tabular}{|c|c|c|c|c|}
\hline Participant & Title & Gender & Office & $\begin{array}{c}\text { Duration } \\
\text { (in minutes) }\end{array}$ \\
\hline Exec01 & CTO/Partner in Charge & $\mathrm{F}$ & $\mathrm{A}$ & 61 \\
\hline Exec02 & $\mathrm{CEO}$ & M & B & 59 \\
\hline Exec03 & HR Director & $\mathrm{F}$ & A & 68 \\
\hline Exec04 & Partner in Charge & M & $\mathrm{D}$ & 57 \\
\hline Exec05 & Shareholder & $\mathrm{F}$ & $\mathrm{C}$ & 69 \\
\hline Exec06 & Shareholder & $\mathrm{F}$ & $\mathrm{D}$ & 68 \\
\hline Exec07 & Shareholder & $\mathrm{F}$ & $\mathrm{B}$ & 67 \\
\hline Mid01 & Senior Manager & M & $\mathrm{C}$ & 67 \\
\hline Mid02 & Senior Manager & $\mathrm{F}$ & B & 53 \\
\hline Mid03 & Senior Manager & M & $\mathrm{E}$ & 58 \\
\hline Mid04 & Manager & M & A & 66 \\
\hline Mid05 & Manager & $\mathrm{F}$ & $\mathrm{C}$ & 64 \\
\hline Mid06 & Senior Manager & M & $\mathrm{F}$ & 55 \\
\hline Mid07 & Senior Manager & $\mathrm{F}$ & $\mathrm{F}$ & 67 \\
\hline Mid08 & Manager & M & $\mathrm{F}$ & 57 \\
\hline Mid09 & Manager & $\mathrm{F}$ & $\mathrm{F}$ & 38 \\
\hline Junior01 & Staff I & $\mathrm{F}$ & B & 45 \\
\hline Junior02 & Supervisor & $\mathrm{F}$ & $\mathrm{B}$ & 55 \\
\hline Junior03 & Staff I & M & A & 62 \\
\hline Junior04 & Senior Accountant & $\mathrm{F}$ & $\mathrm{D}$ & 55 \\
\hline Junior05 & Supervisor & $\mathrm{F}$ & $\mathrm{A}$ & 69 \\
\hline Junior06 & Staff II & $\mathrm{F}$ & A & 55 \\
\hline Junior07 & Senior Accountant & $\mathrm{F}$ & A & 47 \\
\hline Junior08 & Supervisor & $\mathrm{F}$ & B & 53 \\
\hline Junior09 & Staff I & M & $\mathrm{C}$ & 49 \\
\hline Junior 10 & Senior Accountant & M & $\mathrm{F}$ & 22 \\
\hline
\end{tabular}


TABLE 2

\section{Additional Representative Quotes}

\begin{tabular}{|c|c|c|c|}
\hline \multicolumn{4}{|c|}{ Cycle 1 of the Relational Model: Examples of Institutional Complexity and Polarization } \\
\hline & JUNIOR & MID & EXEC \\
\hline 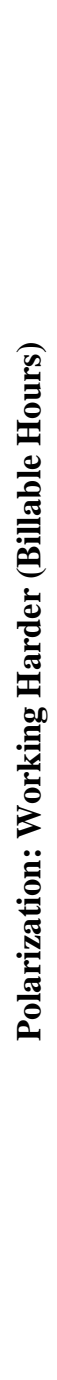 & $\begin{array}{l}\text { [Other juniors] refuse assignments, or } \\
\text { say, 'I don't have time to do that' - } \\
\text { whereas, I might have time to do it, } \\
\text { but I have time because I'm working } \\
15 \text { more hours than they are... That } \\
\text { might be their way of silently } \\
\text { complaining or working } 60 \text { hours in a } \\
\text { week where I'm working } 85 \text { hours in } \\
\text { a week. Where, if we just split that } \\
\text { difference, everybody's working } 70 \\
\text { hours - I'm not saying that everybody } \\
\text { should be working } 70 \text { hours a week, } \\
\text { because it's a lot, but as I get further } \\
\text { and further away from the staff level, } \\
\text { I'm seeing the staff hours decrease } \\
\text { and decrease. (Junior05) } \\
\text { I've been on the [top xx hours] list so } \\
\text { I don't mind because I see my name. } \\
\text { To me, that's the recognition that I } \\
\text { like, but that only works for people } \\
\text { that are motivated like me. Seeing my } \\
\text { name on a list that goes out to } \\
\text { everyone in the firm, that's } \\
\text { motivating for me, but not } \\
\text { everybody's like - most people are } \\
\text { not like me. Most people want to } \\
\text { work a lot, lot less; not work harder } \\
\text { just to see their name on the list. } \\
\text { (Junior05) } \\
\text { [The firm] didn't tell me that we have } \\
\text { to work [as many] hours here [as we } \\
\text { do]. To me, I don't want to be left } \\
\text { behind, so I keep working as other } \\
\text { people are doing here, and also here } \\
\text { people around me who don't get fired, } \\
\text { who stay here, they are [working] } \\
\text { very hard, so that kept me doing the } \\
\text { same way. (Junior07) }\end{array}$ & $\begin{array}{l}\text { There's been staff that haven't met it [the } \\
\text { billable hours target], but those are the } \\
\text { ones that are just maybe there for... a place } \\
\text { holder for now... I'm like 'Your bonus is } \\
\text { driven off this, so maybe you'd want to } \\
\text { work more' ... Maybe they don't have an } \\
\text { incentive of making more money. I don't } \\
\text { know what it is, but we tell them, 'You're } \\
\text { new to this game; you don't know what } \\
\text { the bonus structure is like. This is what it's } \\
\text { driven off, so work'. (Mid05) } \\
\text { We had a staff who was at } 1,600 \text { [billable } \\
\text { hours] and she's like, 'I'm not working } \\
\text { any more than that' ... I was coaching her } \\
\text { and ... the last meeting I had with her, I } \\
\text { was like, 'Listen, you're gonna have to } \\
\text { consider if reduced time is available to } \\
\text { you, but then it's not really fair for the } \\
\text { person next to you, making the same } \\
\text { amount as you', and she said 'I just } \\
\text { thought that } 1,800 \text { was to get a bonus, and } \\
\text { as long as I was working } 40 \text { hours a week, } \\
\text { and then during tax season if ... I was } \\
\text { right around 50, then that was fine'... } \\
\text { She'll tell you, over and over, 'If it came } \\
\text { to me having more family time or } \\
\text { whatever, then I don't need the bonus, so } \\
\text { I'm not gonna worry about getting those } \\
\text { extra hours; I'm doing my job' ... that was } \\
\text { kind of an eye opener for us, but really } \\
1,800 \text { is where you're supposed to start } \\
\text { working up from. (Mid07) }\end{array}$ & $\begin{array}{l}\text { What I used to do, I never missed anything } \\
\text { [e.g. children's activities], is go do that and } \\
\text { then go back to work to make up the time. I } \\
\text { always did that my entire career. What we } \\
\text { are seeing even with the next partner group } \\
\text { - the } 35-45 \text { they are willing to work their } \\
\text { day but when their personal time comes, } \\
\text { they don't come back to work. It's over. } \\
\text { So, what are the staff below them seeing? } \\
\text { You emulate what you see... If they have } \\
\text { a function they need to go to, including .... } \\
\text { weekend in March, I say 'it's our busy } \\
\text { season how are you leaving?' ... 'well I } \\
\text { don't know but I'm going'. It's the concept } \\
\text { of making the time up, 'No, that's my } \\
\text { personal time'. Where, I would go [to the } \\
\text { function], but I would work all day to make } \\
\text { up for the time I spent going ... They don't } \\
\text { go back afterwards, there is no 2nd shift. } \\
\text { They could be right, maybe that is the right } \\
\text { way to do it. I guess if they're being } \\
\text { compensated the same then all power to } \\
\text { them. (Exec04) } \\
\text { Their mindset is different. When I started } \\
\text { in public accounting, you go out onto an } \\
\text { audit and the team of people are there. You } \\
\text { would never think to leave before the in } \\
\text { charge said, 'We're done, let's go' or } \\
\text { 'We're done for the night'. You stayed 'til } \\
\text { everybody was done. We all left as a team. } \\
\text { We have people that say, 'I told my } \\
\text { boyfriend I'd meet him for dinner. I have to } \\
\text { go'. You don't do that but then - they're } \\
\text { not saying it to me, my in charge will call } \\
\text { me and say 'Can you believe she just left' } \\
\text { or 'He just left', and I'm like, 'Why did } \\
\text { you allow that? Why didn't you say we'll } \\
\text { be here tonight 'til } 8 \text { or the client's } \\
\text { allowing us to stay 'till 7' or whatever it is, } \\
\text { or 'We gotta go back to the office because } \\
\text { the client's kicking out at } 5: 30 \text {. We'll just } \\
\text { go back to the office and work'. (Exec06) }\end{array}$ \\
\hline
\end{tabular}




\begin{tabular}{|c|c|c|c|}
\hline 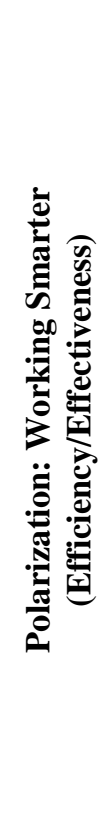 & $\begin{array}{l}\text { I don't think we should be } \\
\text { recognizing people for going crazy } \\
\text { and working all these hours, if they're } \\
\text { not effective hours, which is hard to } \\
\text { say. We're getting into this sense of } \\
\text { recognizing people just because they } \\
\text { stay here 'til } 2 \text { am, even if they are } \\
\text { putting in terrible hours; even they're } \\
\text { not efficient or effective, but it's just } \\
\text { the fact that they have a lot of billable } \\
\text { hours. (Junior03) } \\
\text { There are a lot of staff that put up } \\
\text { very high hours, and the quality of } \\
\text { work isn't as good as those who work } \\
\text { less and fit a lot more quality into } \\
\text { those hours ... So how do we measure } \\
\text { the work that's done by one staff in } \\
\text { half the time - the efficiency and the } \\
\text { effectiveness - versus someone that's } \\
\text { just throwing up hours and throwing } \\
\text { up hours to meet their charge goal, } \\
\text { but requires a lot of rework and a lot } \\
\text { of training? (Junior05) }\end{array}$ & $\begin{array}{l}\text { What usually happens is they take it to a } \\
\text { certain place and then they just stop. } \\
\text { Maybe halfway through the job, maybe } \\
\text { they are getting beaten down by the stress } \\
\text { of balancing multiple engagements, maybe } \\
\text { it's the middle of the busy season and } \\
\text { they're worn out. Whatever it is, the } \\
\text { performance plateaus and then declines to } \\
\text { the point where my phone's ringing all day } \\
\text { long or, if I'm in the field, I'm getting taps } \\
\text { on the shoulder, constantly, and that's } \\
\text { where I go back to not meeting my } \\
\text { performance expectations because you're } \\
\text { not making decisions anymore. (Mid06) } \\
\text { There are people I know ... that are here } \\
\text { all the time, with the hours, but they're } \\
\text { watching television all day, and that's } \\
\text { where managers are most frustrated is } \\
\text { managers are the first line of defense for } \\
\text { the work product and ... it's frustrating to } \\
\text { managers when they know how much } \\
\text { they've had to clean up of somebody's } \\
\text { stuff, or they can see how people are, and } \\
\text { then a staff member is available to a } \\
\text { partner or something. (Mid07) }\end{array}$ & $\begin{array}{l}\text { They're not focusing on hours; they're } \\
\text { focusing on the project. They're project } \\
\text { driven, right? You know the game, the } \\
\text { game's over you're done. I think they look } \\
\text { at it as I finished my project why are you } \\
\text { asking me to do more than what I've } \\
\text { already accomplished? So, you're not } \\
\text { going to get any more out of them. I'm } \\
\text { done for the day; I finished the last thing } \\
\text { before I'm going to go play softball. Now } \\
\text { it's my personal time. (Exec04) }\end{array}$ \\
\hline
\end{tabular}

\begin{tabular}{|c|c|c|c|}
\hline \multicolumn{4}{|c|}{ Cycle 2 of the Relational Model: Examples of Institutional Complexity and Disruption } \\
\hline 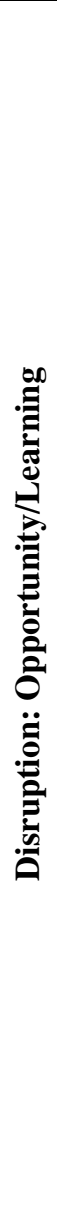 & $\begin{array}{l}\text { I felt very eager to learn. I don't remember } \\
\text { ever saying no to a task, I understand there } \\
\text { are circumstances when you need to say } \\
\text { no. Sometimes you don't have the } \\
\text { capacity. It's April } 12 \text { and you have } 90 \\
\text { hours of work and only } 40 \text { hours to do it, I } \\
\text { understand that, but ... some of the newer } \\
\text { staff turn down opportunities where they } \\
\text { should be jumping at the bit to get } \\
\text { those.... someone's coming up to you to } \\
\text { ask you to do something, and they're } \\
\text { above you, it's not because they don't } \\
\text { want to do it; they probably could do it, } \\
\text { and they could probably do it a lot quicker } \\
\text { than you could and a lot more correctly } \\
\text { than you could, but they want to give you } \\
\text { the opportunity to learn, they want to } \\
\text { invest the time in you. Before you refuse a } \\
\text { project, think about what you're refusing, } \\
\text { and whether that's really an opportunity } \\
\text { for you to grow. I understand there are } \\
\text { times that you need to refuse something, } \\
\text { whether it's you have your own personal } \\
\text { reason and you need to be somewhere, and } \\
\text { maybe you say, 'I can't get it to you } \\
\text { tonight; can I work on this tomorrow? } \\
\text { What's your priority on this?' - saying no } \\
\text { is okay; you just need to deliver the } \\
\text { message correctly. (Junior05) } \\
\text { You don't want to give away work } \\
\text { because then ... you lost the opportunity } \\
\text { to learn about that client, and when time } \\
\text { comes, you're not gonna have any work, } \\
\text { and then you're gonna be like, 'I need } \\
\text { work', so I don't think it's smart to turn } \\
\text { down work. It's better to be, like, 'If it's } \\
\text { not urgent, can I do it later?' (Junior06) }\end{array}$ & $\begin{array}{l}\text { I asked one of the staff the other day, a } \\
\text { staff one; still young, green, but they want } \\
\text { to learn. They want to learn the products } \\
\text { that we use, the data extraction software. } \\
\text { They'll look at it on their own at home to } \\
\text { get things done. If I ask, 'Can you do } \\
\text { this?', 'I don't know if I can but I'll try'. } \\
\text {.. There is [another] one in particular that } \\
\text { is - 'Do you know how to use this } \\
\text { software?', 'No', 'Are you gonna learn?', } \\
\text { 'No', 'Are you gonna go to the seminars } \\
\text { to be taught?' 'No, I didn't think I need to } \\
\text { go. I didn't want to go so I didn't sign up } \\
\text { for it'. It's like, you see your peer who is - } \\
\text { he's wanted on every job, everyone wants } \\
\text { to work with him, he's doing this on his } \\
\text { own to set himself apart, and he is really } \\
\text { setting himself apart from you. So, I asked } \\
\text { [the first staff about the second] and he's } \\
\text { like, 'No, he hasn't said anything about } \\
\text { wanting to excel or do anything extra'. I } \\
\text { pass his cube at 5:00 yesterday, and he } \\
\text { [the second staff] was gone. (Mid05) }\end{array}$ & $\begin{array}{l}\text { I know a young person who works for the } \\
\text { firm in the New York City office and his } \\
\text { question is why should there be such a } \\
\text { concern on the number of hours I do as } \\
\text { long as the quality of what I do and the } \\
\text { efficiency of what I do is better than the } \\
\text { previous person? So why am I being held } \\
\text { accountable to do more hours when my } \\
\text { hours are more efficient? My response is } \\
\text { well, if you work more hours, you're } \\
\text { going to learn more, you'll develop } \\
\text { quicker and you'll provide even more } \\
\text { value. (Exec04) } \\
\text { On a bigger job where they're seeing } \\
\text { more, learning more, there's more going } \\
\text { on, maybe the job takes longer ...it gives } \\
\text { you a chance to get them to really learn. } \\
\text { That's a key to it - they're enjoying the } \\
\text { job. When you're just popping somebody } \\
\text { in and out of a job, one week to the next, } \\
\text { they're barely learning it before they're } \\
\text { running somewhere else, and they don't } \\
\text { get that satisfaction of seeing it all the } \\
\text { way through and learning the whole thing, } \\
\text { so that plays in my mind. (Exec07) }\end{array}$ \\
\hline
\end{tabular}




\begin{tabular}{|c|c|c|c|}
\hline 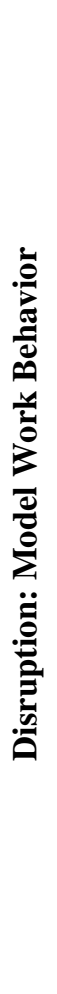 & $\begin{array}{l}\text { Compared to... other professions I think it } \\
\text { [compensation] is appropriate [for the } \\
\text { hours put in]. As far as where I stand } \\
\text { within my group of peers - I'm not sure } \\
\text { where I fall... I may be at the lower end of } \\
\text { the pay range... when I first heard about } \\
\text { it, it bothered me a little, because it } \\
\text { seemed to be a pretty big difference. } \\
\text { We're talking about. a ten-thousand-dollar } \\
\text { difference if it is what they say it is. It } \\
\text { made me question why and then I said } \\
\text { could it be maybe they're putting in more } \\
\text { hours than I am, which is totally possible. } \\
\text { I didn't make my billable hours last } \\
\text { year... I came } 1,750 \text { - } 1,700 \text { - I can't } \\
\text { remember the exact number, but I was } \\
\text { short in hours. (Junior04) } \\
\text { I am [comparing myself to others]. I } \\
\text { always want to be the best... Anyone that } \\
\text { doesn't say that [they are comparing } \\
\text { themselves to others] would be lying. It's } \\
\text { more of you know the baseline. It's your } \\
\text { colleagues; you want to be above. There's } \\
\text { gonna be people below, but ... everyone } \\
\text { has different goals. Um hmm, some } \\
\text { people might just, you know, wanting to } \\
\text { collect the paycheck. (Junior09) }\end{array}$ & $\begin{array}{l}\text { Leadership place value on hours. [They'll] } \\
\text { post the top xx hours for the month. I can } \\
\text { be in that top xx if I choose to. I can } \\
\text { charge my time like a crazy person, blow } \\
\text { my budgets, not be efficient. That doesn't } \\
\text { mean that I'm doing well ... I've known } \\
\text { people on that list, who are ashamed of } \\
\text { the fact that they're on that list because } \\
\text { that means they don't have a life - and it } \\
\text { gets promoted, gets put out there as } \\
\text { something to be proud of. Why am I } \\
\text { gonna be proud of working over } 2,000 \\
\text { hours a month - whatever number of } \\
\text { hours there are ... What does that mean? } \\
\text { What does it say about me? Either I'm not } \\
\text { doing my work right, or I'm doing more } \\
\text { work than I should be doing and } \\
\text { neglecting something else in my life. } \\
\text { (Mid03) } \\
\text { Not everybody wants to work these hours, } \\
\text { not everybody wants to make partner. } \\
\text { They don't find making partner an } \\
\text { attractive deal anymore. It's all I ever } \\
\text { wanted to do it get in, make partner, be } \\
\text { partner ... but you look at the junior staff, } \\
\text { they don't have the same goals - well, not } \\
\text { everyone - but they don't all have the } \\
\text { same goals - to come in here, work hard } \\
\text { and make partner because they'd rather } \\
\text { live their life outside of the firm. (Mid03) }\end{array}$ & $\begin{array}{l}\text { A lot of them it's quality of life. A lot of } \\
\text { them will be, "I don't want to put in the } \\
\text { time I believe it takes to become a partner } \\
\text { in the firm, or the commitment that it's } \\
\text { going to take to be a partner in the firm". } \\
\text { They will tell you, of course, even though } \\
\text { the past five years they've told you, } \\
\text { "Money is everything". Then they will } \\
\text { tell you that "Money is not everything" } \\
\text { when they leave. (Exec04) } \\
\text { They were getting very annoyed when } \\
\text { that email would come out because } \\
\text { they're like - and a lot of them see, like, } \\
\text { partners like myself, you know, they older } \\
\text { partner - you know, I'm not saying old, } \\
\text { but there are older ones than me, but, like, } \\
\text { our generation who really worked hard to } \\
\text { get to where we had to be - we continue } \\
\text { to work hard. I mean, if you have a work } \\
\text { ethic, you're always gonna have a work } \\
\text { ethic. It's just embedded in you. It's just } \\
\text { that you're that kind of person. So, and } \\
\text { they're be like, "Why do I want to work? } \\
\text { I don't want to become a partner. Why } \\
\text { would I want to work that hard?" They } \\
\text { feel like they shouldn't have to work that } \\
\text { hard to make it to that level. (Exec05) }\end{array}$ \\
\hline 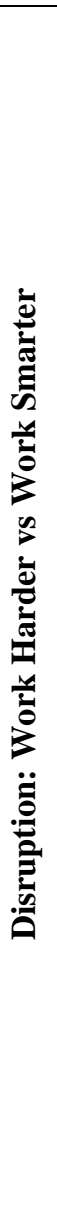 & $\begin{array}{l}\text { Feedback I got was... more of how I } \\
\text { handled an older partner that I was } \\
\text { working with, he would request to have } \\
\text { meetings every other day, and this was } \\
\text { during tax season and I didn't have the } \\
\text { time to meet with him... The feedback } \\
\text { was 'You should try to avoid that, and just } \\
\text { try to not waste so much time with him', } \\
\text { but... he's an older person, so they have- } \\
\text { they're set in their ways, and this is how } \\
\text { they worked, having a meeting and telling } \\
\text { me what to do ... so I was going with the } \\
\text { flow. I didn't want to say, 'No, I can't } \\
\text { meet with you'... I guess it was interfering } \\
\text { with other engagements. (Junior04) } \\
\\
\text { You hear about it [realization] a lot... You } \\
\text { gotta keep efficient [with] certain } \\
\text { managers/partners more than others. Some } \\
\text { want to be profitable and by the book - } \\
\text { 'we're not gonna do more than reasonable } \\
\text { assurance. Let's make money on this'. } \\
\text { Some partners will be, 'We want nothing } \\
\text { wrong with this you're gonna audit to the } \\
\text { last penny'. [Which] makes it hard to stay } \\
\text { within the budget, but, at this level, I don't } \\
\text { answer for that as much ... If I go over a } \\
\text { certain amount of hours someone might } \\
\text { go, 'what happened here?' but ... they do a } \\
\text { good job of making [us] aware that you } \\
\text { don't waste your time. (Junior09) }\end{array}$ & $\begin{array}{l}\text { We're working managers. I like to do the } \\
\text { work, but it's hard to do the work at our } \\
\text { hourly rates because the realization and } \\
\text { all. That's another hard part, too, trying to } \\
\text { manage the time because some things just } \\
\text { take a lot of time, and there are reasons for } \\
\text { it, but say you're on a job and you ask the } \\
\text { staff, 'Why did it take you that long?' } \\
\text { ''Cause it took that long'. You're trying to } \\
\text { make the partners happy, but also we're } \\
\text { closer to the situation, so we do know that } \\
\text { it takes that long, but answering up and } \\
\text { down, it's a tough. (Mid05) } \\
\text { The message from the firm is utilization } \\
\text { and realization, and hammer that home... } \\
\text { it's two different things, right, and } \\
\text { conflicting, right? (Mid06) }\end{array}$ & $\begin{array}{l}\text { I appreciate somebody who gets a job } \\
\text { done efficiently; if they're a little short on } \\
\text { the billable hours, I'm okay with that. } \\
\text { Unfortunately, performance - the } \\
\text { monetary value is tied in with that ... So } \\
\text { you have to get your billable hours in, but } \\
\text { at the same time, worry about realization. } \\
\ldots \text { which conflict ... It happens in this } \\
\text { firm where people put extra hours to make } \\
\text { up hours, and then realization goes crazy. } \\
\text { I know people that are doing it. They're } \\
\text { not telling you that they're doing it, but if } \\
\text { people have to meet billable hours and the } \\
\text { work's not there, and they know they're } \\
\text { gonna be judged based on that, I } \\
\text { guarantee you, an hour's gonna slip here, } \\
\text { an hour's gonna slip there, in order to } \\
\text { meet the billable hours, then you look at } \\
\text { the realization, like, Oh, my God, what } \\
\text { happened? (Exec05) } \\
\text { One [staff] kept [saying] 'I gotta get } \\
\text { billable hours' ... and he was the worst. I } \\
\text { understand the performance measure and } \\
\text { you need to get your billable hours, and if } \\
\text { you don't have enough hours, then you } \\
\text { gotta go to your office manager and say, 'I } \\
\text { don't have enough hours' ... If someone is } \\
\text { not making their billable hours but they're } \\
\text { giving me a good work product, I'm okay } \\
\text { with that ... If the work's just not there, for } \\
\text { whatever reason, but they're doing a good } \\
\text { job, I'd rather have that then somebody so } \\
\text { concerned with billable hours, and their } \\
\text { work product is awful. That's a perfect } \\
\text { example of what happened to that } \\
\text { gentleman. His work product was awful. } \\
\text { (Exec05) }\end{array}$ \\
\hline
\end{tabular}




\begin{tabular}{|c|c|c|c|}
\hline \multicolumn{4}{|c|}{ Cycle 3 of the Relational Model: Examples of Institutional Complexity and Compatibility } \\
\hline & JUNIOR & MID & EXEC \\
\hline 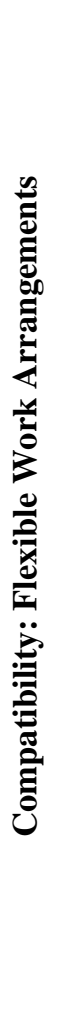 & $\begin{array}{l}\text { I like to take advantage of flex time. We } \\
\text { took that away from staff ones, going } \\
\text { forward. We just find that it gets } \\
\text { mismanaged, or they need more guidance } \\
\text { than, you know, a staff two or a senior, so } \\
\text { having them sit at home and work might not } \\
\text { work because they'd just kind of sit there, } \\
\text { and if they get stuck on something, what do } \\
\text { they do? They either spend too much time } \\
\text { on it and move on, or get it wrong, or, so } \\
\text { staff ones no longer have flex time. I think } \\
\text { they get it back as a senior. (Junior05) }\end{array}$ & $\begin{array}{l}\text { I have unlimited time off ... I don't accrue } \\
\text { time off but it's open time off. It's really a } \\
\text { sham to be honest with you. ... This firm } \\
\text { made the wise decision and said, 'Why } \\
\text { should we carry this liability on the books } \\
\text { for people at this level? They gotta work } \\
\text { around the clock for us anyway, right? So, } \\
\text { why not give them the freedom and the } \\
\text { benefit of just exercising that freedom } \\
\text { whenever they choose?' The reason I say } \\
\text { we kind of work around the clock is we } \\
\text { would not have gotten to this level if we } \\
\text { didn't work a certain way, and if we didn't } \\
\text { feel a sense of responsibility to our clients } \\
\text { and to the firm. They recognized that, and I } \\
\text { give them credit for recognizing that, but } \\
\text { it's a sham, like I said. What am I gonna do } \\
\text { with all that time? (Mid03) } \\
\text { You still know you have obligations; you } \\
\text { still know you have responsibilities. Flex } \\
\text { time or not, we're still gonna do what we } \\
\text { need to do to get our hours in. I didn't need } \\
\text { to work today, with my last four days, but I } \\
\text { still have obligations. Just because I met } \\
\text { and exceeded my } 40 \text { hours for my week } \\
\text { doesn't mean that - 'I'm gonna work } 10 \\
\text { hours a day and not work Fridays'. No, } \\
\text { [that is] not really what it's about. (Mid05) }\end{array}$ & $\begin{array}{l}\text { We have flexibility at different levels. } \\
\text { There have been people, in the past, [who] } \\
\text { took advantage of that flexibility. They } \\
\text { have a pet or something they have to be } \\
\text { home [for], so maybe they stayed home, or } \\
\text { they [only] come to the office on a } \\
\text { Saturday because they figured, why waste } \\
\text { the time commuting? Stay home and work. } \\
\text { You do that once, that's fine; you do that } \\
\text { twice - but now you're doing it more } \\
\text { often, and other people in the office are } \\
\text { looking at that and saying, 'Why is such } \\
\text { and such not in the office?'. But if we } \\
\text { telling them that they have flexibility, and } \\
\text { they're meeting their hours - who cares } \\
\text { where they're working? ... we're sending } \\
\text { a little bit of a mixed message, in that } \\
\text { respect. (Exec05) } \\
\text { If you need to come in at } 9 \text { and work to } 6 \text {, } \\
\text { that's okay ... Or if you need to leave for } \\
\text { an hour and a half because you have a } \\
\text { doctor's appointment, then you want to } \\
\text { work a little bit later, that's fine. But ... 'I } \\
\text { want to work from home every Friday', } \\
\text { they don't understand that that's not what } \\
\text { this is all about. I feel like we don't set } \\
\text { expectations clearly. We're really not that } \\
\text { flexible, but we try and say that we are. } \\
\text { We care about people's work/life balance, } \\
\text { but you better get your job done. (Exec06) }\end{array}$ \\
\hline 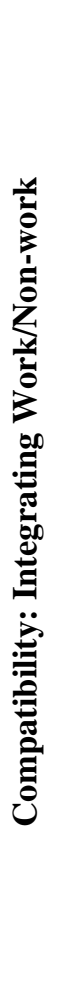 & $\begin{array}{l}\text { We use flex time, so you can move your } \\
\text { hours around. When I started, the } \\
\text { explanation was you can [use it], but you } \\
\text { have to make up the time somewhere else... } \\
\text { I definitely know people that do that, } \\
\text { especially during busy season it's easy } \\
\text { because there's so much that you can do, } \\
\text { but that takes a little bit more forward } \\
\text { thinking of being, 'I'm gonna be leaving } \\
\text { early this day, so I need to talk with } \\
\text { someone to get work'. Whereas, I'm at the } \\
\text { point where ... there's always something I } \\
\text { can do, wherever I am, as long as I have my } \\
\text { laptop, I can make up the hours. (Junior02) } \\
\text { I think I have work/life flexibility; I don't } \\
\text { know if I have work/life balance. Balance } \\
\text { implies 50/50, I don't think that's possible, } \\
\text { but I have work/life flexibility. I'm able to } \\
\text { work when I need to work, and I'm able to } \\
\text { take off days when I need to, and schedule } \\
\text { my own time off, and if I need to come in at } \\
11: 00 \text { on one day for any reason, I can do } \\
\text { that and it's not a big deal, so I think [the } \\
\text { firm is] good at making your life - making } \\
\text { work fit into your life and not the other way } \\
\text { around, so I don't want to say 'balance'. } \\
\text { (Junior05) }\end{array}$ & $\begin{array}{l}\text { When I can or when I need to [I use flex } \\
\text { time]. Like, today I'll probably leave a } \\
\text { little earlier because my best friend's bridal } \\
\text { shower is on Sunday, so I have a few things } \\
\text { to do, but I'll work tonight, so I like to do } \\
\text { that, but I'm not gonna let my obligations } \\
\text { go to the wayside because of it... I like } \\
\text { being able to work from where I need to, } \\
\text { (Mid05) } \\
\text { What I found here is that, as long as I work } \\
\text { hard and get my work done, which may } \\
\text { require a lot of hours sometimes, I still } \\
\text { rarely miss something, you know, with my } \\
\text { kids. I'm still at their events and do those } \\
\text { things. It might require that work late at } \\
\text { night and do those things, but most of the } \\
\text { time I can go to everything. (Mid07) }\end{array}$ & $\begin{array}{l}\text { I'm rarely ever missing a [kid's] sporting } \\
\text { event. I never miss a doctor's } \\
\text { appointment... It's always been ''I need } \\
\text { to leave at } 3 \text { o'clock today, I'll be back } \\
\text { online tonight'. I always knew if I had to } \\
\text { adjust my schedule, I knew I had to work } \\
\text { later and they went to bed. They didn't see } \\
\text { me working or I make up the time and if I } \\
\text { didn't make up the time it's on me ... My } \\
\text { first boss always told me, I'm not a } \\
\text { morning person, 'I don't care about time } \\
\text { you get in as long as you get your work } \\
\text { done. And I'll treat you like a } \\
\text { professional'. That's what we've always } \\
\text { done. We treat everyone like a } \\
\text { professional until we feel like we're been } \\
\text { taking advantage of ... For me, I've } \\
\text { always lived by that flexibility. (Exec01) } \\
\text { The last thing you want to do is say 'This } \\
\text { is how we used to do it. This is the } \\
\text { expectation because this is what I had to } \\
\text { do'. That's what you don't want to do, } \\
\text { right? 'Cause they don't want to be like } \\
\text { you. That's the last thing they want. } \\
\text { Unfortunately, we have certain partners } \\
\text { who are like, 'I don't care if you have to } \\
\text { stay all weekend - you've just got to get } \\
\text { the job done' or whatever. They're just } \\
\text { old school in their thinking: 'We do it this } \\
\text { way every year'. (Exec04) }\end{array}$ \\
\hline
\end{tabular}


